\title{
Lumen
}

Selected Proceedings from the Canadian Society for Eighteenth-Century Studies

\section{Indicting the Woman Artist: Diderot, Le Libertin, and Anna Dorothea Therbusch}

\section{Bernadette Fort}

Volume 23, 2004

URI : https://id.erudit.org/iderudit/1012185ar

DOI : https://doi.org/10.7202/1012185ar

Aller au sommaire du numéro

Éditeur(s)

Canadian Society for Eighteenth-Century Studies / Société canadienne d'étude du dix-huitième siècle

ISSN

1209-3696 (imprimé)

1927-8284 (numérique)

Découvrir la revue

Citer cet article

Fort, B. (2004). Indicting the Woman Artist: Diderot, Le Libertin, and Anna Dorothea Therbusch. Lumen, 23, 1-37. https://doi.org/10.7202/1012185ar

Copyright (C Canadian Society for Eighteenth-Century Studies / Sociéte canadienne d'étude du dix-huitième siècle, 2004
Ce document est protégé par la loi sur le droit d'auteur. L'utilisation des services d'Érudit (y compris la reproduction) est assujettie à sa politique d'utilisation que vous pouvez consulter en ligne.

https://apropos.erudit.org/fr/usagers/politique-dutilisation/ 


\section{Indicting the Woman Artist: Diderot, Le Libertin, and Anna Dorothea Therbusch}

Nearly thirty years ago, Ann Sutherland Harris and Linda Nochlin devoted a large-scale exhibition to the forgotten half of Western painting since the Renaissance, 'Women Artists: $1550-1950 .^{2}$ Since then, a number of single-artist exhibitions, important catalogues and books have focused on the most prominent of these female painters, including three late eighteenth-century French artists, the still-life painter Anne Vallayer-Coster and the portraitists Adélaïde Labille-Guiard and Elisabeth Vigée-Lebrun. ${ }^{3}$ Among the many obstacles these three women had to overcome to secure their reception at the Royal Academy of Painting and the esteem of the critics and the public at the biennial Salons of the Academy were entrenched anxieties and prejudices that attached to their gender. ${ }^{4}$ Their works, which rivaled in all respects the best paintings by

1 I would like to thank the audiences of the Centre canadien d'études allemandes et européennes at the Université de Montréal and of the colloquium 'Representation in the Eighteenth Century' at the University of Koblenz-Landau, where I delivered earlier versions of this essay in October 2002 and June 2003 respectively.

2 Ann Sutherland Harris and Linda Nochlin, Women Artists: 1550-1950, exhibition catalogue (New York: Alfred A. Knopf, 1976). The exhibition took place at the Los Angeles County Museum of Art.

3 See Eik Kahng and Marianne Roland Michel, eds., Anne Vallayer-Coster, Painter to the Court of Marie-Antoinette (New Haven and London: Yale University Press, 2002); Anne-Marie Passez, Adélaïde Labille-Guiard, 1749-1803. Biographie et catalogue raisonné de son auvre (Paris: Arts et Métiers graphiques, 1973); Joseph Baillio, Elisabeth Louise Vigée Lebrun, 1755-1842 (Fort Worth: Kimbell Art Museum, 1982); and Mary Sheriff, The Exceptional Woman: Elisabeth Vigée-Lebrun and the Cultural Politics of Art (Chicago: Chicago University Press, 1996). Marianne Roland Michel had already argued for a reconsideration of the work of the still-life painter Anne Vallayer-Coster in 1970 (Anne Vallayer-Coster, 1744-1818, Paris: Comptoir international du Livre, 1970).

4 For example, a critic wrote in 1783: 'Jusqu'a présent, on n'attendait de leur pinceau que de l'agrément \& de la propreté; elles montrent aujourd'hui de la vigueur \& de la 
male academicians, confronted critics with the task of making sense of their dual identity as 'women artists,' a concept which to most appeared as an impossible oxymoron.

The present essay focuses on an earlier text of art criticism, the article written by the philosophe and prominent art critic Denis Diderot in his Salon of 1767 on the Prussian painter Anna Dorothea Therbusch (17211782), who traveled from Berlin to Paris in the summer of 1766 to seek fame and glory in the European capital of the arts. Diderot's piece, which takes up no fewer than eight pages in the DPV critical edition, combines a caustic account of her mixed reception in Paris and at the Academy with a highly critical review of some of her paintings, and culminates in a startling anecdote of a sitting when he stood model to her for his portrait. ${ }^{5}$ For a long time neglected by Diderot critics, this text has resurfaced in the few biographies and catalogues that punctuated the slow rediscovery of Therbusch in twentieth-century Germany: Leopold Reidemeister's unpublished doctoral thesis (Berlin, 1924), based in part on the biographical essay by Johann Georg Meusel (1783); Gerd Bartoschek's catalogue of the first retrospective exhibition of her paintings at Potsdam-Sanssouci for the 250th anniversary of her birth in 1971; Ekhart Berckenhagen's important 1986 article containing a catalogue (Werkverzeichnis) of over 200 of her works; a well-informed essay by Thierry Bajou on her Paris sojourn (2000); and, lately, a useful essay by Katharina Küster in the catalogue of an exhibition on portraiture devoted to Therbusch and her contemporary Ludovike Simanowiz in Ludwigsburg, Germany (2002-2003). ${ }^{6}$ Diderot's text thus figures for

noblesse; et les hommes qui s'étoient attribué sur elles toute la supériorité des talens, peuvent désormais craindre la concurrence' (Loterie pittoresque pour le Salon de 1783, p. 14). See also Emma Barker, 'Women Artists and the French Academy; Vigée-Lebrun in the 1780s,' Gender and Art, ed. Gill Perry (New Haven and London: Yale University Press, 1999), p. 108; Melissa Hyde, 'Women and the Visual Arts in the Age of Marie-Antoinette,' in Anne Vallayer-Coster, eds. Eik Kahng and Marianne Roland Michel, p. 75-93.

5 Diderot, Salons III: Ruines et paysages. Le Salon de 1767, textes établis et présentés par Else Marie Bukdahl, Michel Delon, Annette Lorenceau (Paris: Hermann, 1995), p. 369-77. Page numbers will be cited in the text.

6 Leopold Reidemeister, 'Anna Dorothea Therbusch: ihr Leben und Werk,' Dr. diss. Friedrich-Wilhelms-Universität zu Berlin, 1924 (typescript). Gerd Bartoschek, Anna Dorothea Therbusch, 1721-1782, exh. cat. im Kulturhaus 'Hans Marchwitza' (Postdam-Sanssouci, 1971). Ekhart Berckenhagen: 'Anna Dorothea Therbusch,' Zeitschrift des deutschen Vereins für Kunstwissenschaft 41 1/4 (1987), p. 118-60. Thierry Bajou, 'Eine deutsche Künstlerin im Paris des 18. Jahrhunderts: Anna Dorothea 
German art-historical scholarship as an important documentary source on Therbusch's controversial reception at the Royal Academy in 1767 and on her turbulent stay in Paris. Yet Diderot's Salon criticism is notoriously complex, multi-layered, and often conflicted. His piece on Therbusch is no exception. While the philosophe sets out to understand the new phenomenon of the 'woman artist,' and indeed at first eloquently voices his support of Therbusch's artistic ambition, the whole rhetoric of the piece ends up indicting both the woman and the artist. If Diderot's review can figure as a document in Therbusch's aesthetic re-evaluation, it should not be as a transparent or reliable historical account, but, rather, I hope to show, as an outstanding example, indeed as the prototype, of a gender-inflected art criticism that contains the seeds of what would be longstanding hostile attitudes toward women painters. ${ }^{7}$ That Diderot's 1767 disparaging verbal portrayal of the Prussian artist remains influential in France today will be gauged by examining at the end of this essay a play by Eric-Emmanuel Schmitt (1997) and its film version by Gabriel Aghion (2000), both entitled Le Libertin, which restage Diderot's narrative of his close encounter with 'Madame Terbouche.'

Born in a family of Polish artists and trained in Berlin by her father, the portraitist Georg Lisiewski, who was court painter to the king of Prussia, Anna Dorothea Therbusch learned portraiture in her teens, and her talent in this line of painting was to open her life-long access to Frederic II and his court: she brought his portrait by her to Paris and after her return to Berlin in 1768 received a commission for eight more full-length portraits of the Prussian family (fig. 1). Unlike French women painters who were limited by academic conventions and social bienséances to the so-called 'lower genres' of painting - still life, miniature,

Therbusch,' Jenseits der Grenzen: Französische und deutsche Kunst vom Ancien Régime bis zur Gegenwart, Thomas W. Gaehtgens zum 60. Geburtstag (Köln: Dumont Buchverlag, 2000), p. 249-68. Katharina Küster and Beatrice Scherzer, Der freie Blick: Anna Dorothea Therbusch und Ludovike Simanowiz. Zwei Porträtmalerinnen des 18. Jahrhunderts (Heidelberg: Kehrer Verlag, 2002). Johann Georg Meusel's 'Lebensumstände der im Jahr $1782 \mathrm{zu}$ Berlin verstorbenen Madame Terbusch' (Miscellaneen artistischen Inhalts [Erfurt, 1783, 3, no. 17], p. 266-75), written shortly after her death, shows no knowledge of Diderot's text. For a short biography in English, see the entry 'Anna Dorothea Lisiewska-Therbusch' in Harris and Nochlin, Women Artists, p. 169-70. I am grateful to Anja Müller-Muth and Patricia Crown for access to some of the German sources.

7 See Rozsika Parker and Griselda Pollock, Old Mistresses; Women, Art, and Ideology (New York: Pantheon Books, 1981), p. 127. 
and portraiture (preferably in pastel rather than oil) - Therbusch set her ambitions higher and practiced all genres, including history painting. She started out copying the fêtes galantes of Antoine Pesne, who was active in Potsdam in her youth, and soon attempted to emulate Pesne's French models, the dazzling paintings of Watteau, Lancret, and Pater, which were highly prized by Frederic II and his court. One of her best-known works in this genre, The Swing (fig. 2), depicts an insouciant society of men and women in a Watteau-like park landscape and includes echoes of, if not direct references to, a lute player by Watteau (The Love Lesson, Stockholm) and a dancing couple in Lancret's Pastoral Dance (Schloß Sanssouci). Despite undisputed success in fêtes galantes, she wanted to broaden her range and experimented with Dutch genre scenes in the taste of Gérard Dou. At the age of forty, having reared her three children, she left Berlin, with her husband's approval, to seek international recognition, following in the footsteps of the renowned Italian painter Rosalba Carriera. She stayed two years at the court of Stuttgart, winning recognition from Carl Eugen, Duke of Württemberg, who, among other honours, entrusted her with a decorative project for his new Residenz. In 1761 her artistic talent was recognized by the Accademia of Bologna, and the Stuttgart Académie des arts made her an honourary member in 1762. She went on to reap more honours at the court of Mannheim, where she painted the Kurfürst Karl Theodor in flamboyant colours and received further commissions from the Prince of Hohenzollern-Hechingen. Therbusch also painted herself at different stages in her career, always displaying originality and wit in the choice of composition, decor, pose, and accoutrements (including, in her late years, a monocle, which became the emblem of her persistence with art despite failing eyesight). ${ }^{8}$ Among her twelve self-portraits, a splendid one, executed at the beginning of her international career in 1761 (fig. 3), shows her in a self-assured pose, holding brushes and palette in her hand, a woman in her early forties who proudly displays her art-making as inseparable from her femininity. ${ }^{9}$ The mystery of her smile is enhanced by her coyly averted eyes. Her dark, curled hair, is unpowdered and worn loose over a dark brown robe with white satin lining. The left side of her upper body is tantalizingly unveiled and her breast enhanced by

8 On the representation of the aging artist, see Patricia Crown, 'Eighteenth-Century Images of the Aged Woman Artist' (The Maxine Christopher Shutz Award and Lecture for Distinguished Teaching), The University of Missouri-Columbia, 2003.

9 For colour reproductions of some of these self-portraits, see the catalogue of the 2002 exhibition in Ludwigsburg cited in note 6. 
a transparent camisole. Modestly covering her cleavage, a white muslin scarf brings out the milky colour of her skin. The whole painting combines feminine attractiveness with a sure display of artistic talent.

Therbusch's success at the courts of Berlin, Stuttgart, and Mannheim, along with the honours and lucrative commissions she had garnered there, had not prepared the artist for the indifference, if not diffidence, with which her arrival was met in Paris and Versailles. ${ }^{10}$ According to Diderot, she soon found herself looking for support, connections, and clients. His analysis of her failure to secure royal protection is couched in a bitter indictment of the closed system of favoritism prevalent at court:

Il fallait que la dame prussienne, débarquant à Paris, y fût précédée et soutenue des éloges éclatants des ambassadeurs étrangers qui n'ont vu que leur pays. Nos talons rouges n'auraient pas tardé à faire écho. Conduite, célébrée, occupée à Versailles, elle aurait pu descendre jusqu'au désir d'entrer à l'Académie qui peut-être l'aurait refusée, car volontiers Paris ne souscrit pas aux applaudissements de Fontainebleau; mais alors le blâme et les cris du monde courtisan seraient revenus sur la pauvre Académie. [...] On aurait clabaudé; on aurait dit, ils n'en veulent point, à la bonne heure; mais il faut que le roi ait un ou plusieurs tableaux d'une femme aussi célèbre. Alors Cochin sachant que son ami Diderot s'y intéresse, fausse un peu la balance, appuie la demande, ce petit poids détermine; les artistes crient; on leur répond, que diable, la protection; ils sont faits à ce mot; ils se taisent et rient. (p. 376-77.)

What Diderot is describing here, with a cynicism based on a longstanding insight into the complex channels of artistic advancement in eighteenth-century Paris, is the structure of privilege inbred in the absolutist regime, in which a recommendation formulated by a courtier was able to override the authority of the very institution founded by the king to arbitrate all matters of aesthetic judgment, the Royal Academy. Therbusch had brought with her letters of introduction from Philippe de la Guêpière, court architect to the Duke of Württemberg and from the Count of Schullenburg, lieutenant general of Frederick II. These were enough to prompt the Marquis de Marigny, directeur des Bâtiments du roi and Mme de Pompadour's brother, to inquire from Charles-Nicolas Cochin, his trusted adviser and the Royal Academy's secretary, whether

10 I disagree with Thierry Bajou, who writes that her Parisian sojourn began 'under the most favorable signs' (p. 251) and that she rapidly achieved success in Paris. 
'cette célèbre Berlinoise' deserved royal patronage. Cochin's positive response may have been influenced by Diderot's intervention, as the critic claimed. However, cited in its entirety, as is rarely done, it appears as a model of guarded encouragement, and it prefigures the reservations that Diderot would manifest in his own review of the artist's work a year later. It attests to the ambivalence that greeted unusual female achievement in the arts at that time. Cochin highlights Therbusch's impressive artistic merit, but he portrays this merit as a rarity, as a curiosity worthy of support precisely in view of the painter's gender, and all the more remarkable as she had to transgress the rules of bienséance to paint the male nude:

J'ay vu les ouvrages de cette dame, peintre du roy de Prusse; il y a en effet du talent, au-dessus à [sic] ce que l'on s'attend à en trouver dans une personne de son sexe, et d'autant plus singulier qu'elle peint l'histoire et le nu comme pourroit faire un homme; aussi a-t-elle eu le courage d'étudier d'après nature, en se mettant au-dessus des discours. ${ }^{11}$

Cochin here alludes to the prohibition of women from studying the live model for reasons of decency, although he indicates that there was a precedent in the 'fameuse demoiselle Stella' who studied the model at her father's side. Unwilling to tip the scale of judgment one way or the other, Marigny's adviser falls back on national prejudice, stating that Therbusch's work possesses 'le mérite et les défauts de l'école allemande.' He blames her incorrect drawing and her reddish colour ('son dessin n'est pas correct, et sa couleur est trop rouge'), but admits: 'elle a cependant souvent des tons précieux et chauds, un pinceau large, facile et hardi, joint à un moëlleux agréable dans son exécution.' His final verdict returns, however, to the issue of gender, thereby diminishing while professing to raise - the merit of her work: 'Enfin, elle a un vray mérite, surtout si l'on considère son sexe et les difficultés qu'elle a eues à surmonter pour en arriver à ce degré.' In regard to Therbusch's great wish to do 'un petit morceau pour le roi, ${ }^{12}$ he suggests that a small

11 Marc Furcy-Raynaud, ed., Correspondance de M. de Marigny avec Coypel, Lépicié et Cochin, in Nouvelles Archives de l'Art français, 3e série, t. 20, no. 524, Année 1904 (Paris, 1905), p. 69.

12 This is corroborated by Diderot: 'Sa fantaisie était de faire un tableau pour le roi.' Diderot warned her that she would be either refused or not paid, since in France, ministers 'refusent des acomptes sur [le tableau] qu'ils ont ordonné à des hommes du premier ordre' (p. 376). 
commission might be a 'cadeau délicat, flatteur pour elle et peut-être très agréable au prince à qui elle est attachée [Frederick II].' Such a painting might not, he adds, be of the first artistic order, but il deviendroit intéressant à cause de sa singularité. ${ }^{13}$

Either because the recommendation did not come from an ambassador, or because Marigny did not care for paintings in the German manner, or, more likely, because he did not want to be perceived as encouraging a woman 'who painted the nude like a man,' Cochin's recommendation fell on deaf ears, and Therbusch was left to find work in Paris as best she could. She met Diderot in the circle of German émigrés, travelers, and visitors that gravitated around Frédéric Melchior Grimm, Diderot's friend and the editor of the exclusive and clandestine Correspondance littéraire, where Diderot's Salons regularly appeared since 1759. According to Diderot, Therbusch had come to Paris in the company of a certain Desbrosses, rumored to be a secret agent of Frederick II. ${ }^{14}$ She arrived in the capital at an opportune moment to solicit and receive Diderot's protection. Indicting the French monarchy's failure to practice an enlightened politics of artistic patronage, Diderot in the mid-1760s was experimenting with a unique form of alternate patronage, carving out for himself a role as intermediary between artists and wealthy patrons, including foreign royalty. Within a few months, Therbusch became a great beneficiary of this unique form of private patronage. Diderot bought some of her work, including a Cléopâtre 'vraiment fort belle,' before which he said he genuflected every morning. ${ }^{15}$ His correspondence between October 1766 and November 1768 shows him exerting himself to secure work for 'Madame Terbouche' from a wide array

Cochin to Marigny, see note 11, p. 69.

14 Writing to Grimm in November 1769 just after Desbrosses's suicide (caused by the discovery of a financial scam), a year after his break with Madame Terbouche, Diderot gave interesting particulars: 'L'artiste prussienne et lui s'étoient rencontrés dans une cour d'Allemagne. Il nous l'avoit amenée après avoir circulé dans plusieurs Etats où il avoit montré beaucoup de capacité [...] La Prussienne, dont le comte de Schullenbourg et vous m'aviez embâté, lui a coûté un argent infini. Sa mort l'aura soulagée d'une dette considérable.' Diderot, Correspondance, ed. George Roth (Paris: Éditions de Minuit, 1958-73), vol. 9: p. 222-23. It is likely that Therbusch used Desbrosses's financial skills to borrow large sums of money that she did not repay. Diderot, who had befriended Desbrosses and was greatly affected by his suicide, reported that he died from a bullet in the head and was found 'la tête penchée sur sa table, devant un portrait du roi de Prusse' - perhaps a reduction of the large one painted by Therbusch and brought with her from Berlin. 
of foreign and French patrons. He obtained commissions for her from his friend Prince Dimitri Aleksejevitsch Gallitzin, Catherine II's ambassador to Louis $\mathrm{XV}$, and from the Tsarina herself. ${ }^{16}$ Acting freely as a 'donneur d'idées' to the German artist, as he had to French artists before, he suggested she paint a work exalting the Tsarina as an enlightened ruler ('oubliant l'autorité suprême pour n'écouter que la justice et la bonté, et consultant ses sujets sur des lois qu'elle était maîtresse de leur imposer'), and smugly reported Therbusch's approval of his idea: 'J'entends, dit madame Terbouche, et je serais bien maladroite si je ne faisais rien avec cela. ${ }^{17}$ To allay Therbusch's penury, he obtained permission for her to use the 'petite maison rue d'Anjou' leased by Gallitzin from the sculptor Falconet, who had left for St. Petersburg at Catherine's invitation. ${ }^{18}$ This house became the site of a curious hoax masterminded by Diderot, in which Desbrosses, disguised as a Turkish doctor and with Therbusch at his side, tries to induce Gallitzin's former mistress Mlle Dornet to return portraits of the prince prior to the latter's wedding with Amalia von Schmettau. This hoax, restaged in Diderot's playlet Mystification, ou histoire des portraits (published for the first time in 1953 with drawings by Picasso), emblematizes the international and socially mixed character of the company in which the French philosophe and the needy Prussian artist moved at the time. Diderot also urged his closest friends, including Mme d'Épinay, Grimm, Mme de Maux, Damilaville, and Sophie Volland, to commission paintings from the artist, intimating that they could negotiate advantageous rates, since she was in no position to demand high fees: 'Madame Therbouche,' he wrote to Mme d'Épinay in October 1767, 'a jusqu'à ce jour exercé son art avec toute sa libéralité. Elle ne met aucun prix à son ouvrage. Elle fait de son mieux, et l'on fait avec elle comme on veut. Vous aurez une courtisane grecque faisant pendant à une vestale romaine; et vous jugerez par vous même du rapport de son travail et de son talent, avec le prix misérable qu'on y met. ${ }^{19}$ His

16 In his catalogue of Therbusch's works (Werkverzeichnis: WV), Berckenhagen lists seven paintings by Therbusch that Gallitzin acquired for Catherine II: Vanity, A Bacchant, A Young Shepherd (WV nos. 141-43), Dinner by Candlelight (WV no. 145), Jupiter and Antiope (WV no. 179), Artemisia (WV no. 189), and Cleopatra (WV no. 190), all painted in Paris in 1766-68.

17 This fragment was published for the first time in Diderot Studies 3 (1961): p. 215-17. See also Diderot, Salon de 1767, Annexe V, p. 518-19. Therbusch never executed this painting.

18 See Diderot, Correspondance, 8: p. 29.

19 Diderot, Correspondance, 7: p. 172. In the same letter, pleading his own poverty, he 
correspondence shows his exertions in both directions, on the one hand instigating new commissions from patrons, on the other urging the artist to complete commissioned works. In November 1767, he wrote to Mme d'Épinay: 'Les deux têtes de madame Terbouche pour d'Amilaville sont faites. / J'ai voulu que celles de Grimm pour vous le fussent aussi, et elles le sont. Vous aurez les vôtres lundi, demain, ou mardi, et Madame de Maux les siennes.' Commissions given to Therbusch were apparently maximized by each patron's commitment to buy at least two heads from the artist, as well as by reciprocal arrangements between individual patrons involving Diderot both as the model and broker of portraits by her: 'La condition était que Grimm vous donneroit ces deux têtes, et que vous feriez achever mon portrait pour lui. / Cette condition tient-elle toujours? ${ }^{20}$ As a result, Therbusch's work in Paris seems to have been largely sustained by the network of private patrons that Diderot mobilized on her behalf.

Diderot, however, had little power over the Academy's decision to receive Therbusch as a foreign member when she made a bid for it in February 1767. His text provides a rare insight into - as well as a chilling account of - the intimidation techniques used by this entrenched male academic body against the few women artists who sought to penetrate its ranks:

Elle arrive. Elle présente à l'Académie un premier tableau de nuit assez vigoureux. Les artistes ne sont pas polis. On lui demande grossièrement s'il est d'elle. Elle répond que oui; un mauvais plaisant ajoute, et de votre teinturier. On lui explique ce mot de la farce de Patelin qu'elle ne connaissait pas. Elle se pique. Elle peint celui-ci qui vaut mieux et on la reçoit. (p. 371)

Diderot's testimony here confirms the well-documented practice of French academicians systematically to raise doubts about the authenticity of paintings by women artists. ${ }^{21}$ His review, however, is the first text

suggests that Mme d'Épinay commission a portrait of herself for her daughter: 'Hélas, je n'ai pas le sol. Cela est bien triste. Et si l'on faisait le vôtre, pour votre fille?', 7: p. 172.

Diderot, Correspondance, 7: p. 210-11.

21 This had been the case with Margareta Havermann, who was excluded from the Academy a year after her reception because of such doubts. In Diderot's time, suspicion was raised concerning Anne Vallayer-Coster and, in the 1780s, Adélaïde Labille-Guiard and Elisabeth Vigée-Le Brun (on the latter, see, for example, Les Salons des 'Mémoires secrets,' ed. Bernadette Fort [Paris: École nationale supérieure des Beaux-Arts, 1999], p. 255 and p. 358 n. 5). Meusel indicates, without any support 
not only to identify the Academy's sexist bias as such, but also to denounce an artistic culture in which women could hope to enter the Academy only through gifts of beauty, flattery, or sexual favors:

Ce n'est pas le talent qui lui a manqué pour faire la sensation la plus forte dans ce pays-ci. Elle en avait de reste. C'est la jeunesse, c'est la beauté, c'est la modestie, $c^{\prime}$ est la coquetterie. Il fallait s'extasier sur le mérite de nos grands artistes; prendre de leurs leçons, avoir des tétons et des fesses et les leur abandonner. (p. 371)

Diderot's coarse sexual language indicts the Academy's masculinist and narcissistic culture, and his blunt diagnosis emphasizes that Therbusch failed at first at the Academy not because she was a mediocre artist, but because she rejected the role of sexual object that was expected of her and refused to flatter inflated male egos.

Despite these obstacles, on 28 February 1767 Therbush was both agréée and reçue as académicienne in the same session by the Royal Academy. This was not a sign of distinction, but a result of gender discrimination, as female artists, who could not be promoted within the academic hierarchy, occupied a status apart from their male colleagues. Among the works she presented, the Academy chose as her reception piece a painting in a category deemed suitable to her gender, genre painting. ${ }^{22}$ This work, Un homme, le verre à la main, éclairé d'une bougie (fig. 4), ${ }^{23}$ represents a knee-length male figure leaning at a table under a lamp that lights his face and figure sharply while the rest is plunged in quasi-darkness. This was an ambitious piece in the Dutch manner designed to display to advantage the artist's technical command and manipulation

(p. 269-70), that Therbusch was required to prove herself by executing a painting in front of artists who served as eye-witnesses in her studio - an affirmation repeated by Reidemeister (p. 31).

22 The Procès-verbal of Therbusch's reception reads: 'La dame Anna Dorothea Leicenska [sic], épouse du Sr. Therbusch, née à Berlin, Peintre, ayant fait présenter de ses ouvrages, la Compagnie, après avoir pris les voix à l'ordinaire et reconnu sa capacité, a agréé sa présentation. Et, s'étant trouvé, dans le nombre des tableaux qu'elle a présentés, un tableau dont elle pouvait disposer, représentant une demi-figure, appuyé sur sa main droite et éclairé d'une bougie, l'Académie l'a accepté pour sa réception.' Arnold de Montaiglon, Procès-verbaux de l'Académie royale de Peinture et de Sculpture, 1648-1793, 10 vols. (Paris, 1875-1892), 7: p. 353-54.

23 The place where this painting was exhibited at the Salon can be seen on the far left of a drawing by Gabriel de Saint-Aubin (private collection), reprinted in the exhibition catalogue, Diderot et l'art de Boucher à David, eds. Marie-Catherine Sahut and Nathalie Volle (Paris: RMN, 1984), p. 91, ill. no 27. 
of chiaroscuro. The critic of the Correspondance littéraire - most likely Grimm himself - praised this effect: 'Cet effet de lumière m'a paru beau. On remarque d'ailleurs dans les tableaux de Madame Terbouche de la facilité et une grande liberté de pinceau.' But he added a sly qualification, which is usually not quoted, as it seems so extraneous to Therbusch's art: 'Je ne sais si la correction du dessin répond à ces qualités. Ce que je sais, c'est qu'en recevant Madame Terbouche, l'Académie ne peut être soupçonnée d'avoir déféré à l'empire de la beauté, si puissant en France, car la nouvelle académicienne n'est ni fort jeune, ni jolie. ${ }^{24}$ Slipping insidiously from an evaluation of the artist's craft to that of the woman's age and looks, this gratuitous remark, ostensibly designed to commend Therbusch's artistic feat in gaining membership in the Royal Academy, does so at the expense of the woman's attractiveness. As Grimm's comment shows, a woman's art-making could not, in the eyes of the contemporary male public any more than in the eyes of the male academicians, be divorced from considerations of her sex. This perfidious gender bias would be more than confirmed by Diderot's review.

Diderot, too, opened his Salon entry on Therbusch with a review of the Buveur, but, contrary to the academicians, who had elevated it to the high status of a reception piece, and to other critics who wrote positively about it ${ }^{25}$ he pronounced a scathing verdict on this 'gros réjoui.' Safe from censorship and the retaliatory wrath of the artists, the Academy, and the regime, since his Salons appeared in Grimm's clandestine Correspondance littéraire, Diderot enjoyed a freedom of speech unique in contemporary art criticism. He used this privilege to lambast the painting's Caravaggesque pretensions, its artificial and exaggerated light, its lack of nuance, and its dry and excessive chiaroscuro:

Cela est roide et sec, dur et rouge. Cette lumière n'est pas celle d'une bougie. C'est le reflet briqueté d'un grand incendie. Rien de ce velouté noir, de ce doux, de ce faible harmonieux des lumières artificielles. Point de vapeur entre le corps lumineux et les objets. Aucuns de ces passages, point de ces demi-teintes si légères qui se multiplient à l'infini dans les tableaux de nuit et dont les tons imperceptiblement variés sont si difficiles à rendre. (p. 370)

24 Correspondance littéraire, 15 February 1767, ed. Maurice Tourneux (1879), 7: p. 247-48.

25 See Abbé de la Garde, 'Suite des Observations sur les tableaux, sculptures et gravures exposés au Sallon du Louvre, le 25 août 1767,' Mercure de France (Octobre 1767): p. 176; Élie-Catherine Fréron in L'Année littéraire (24 Septembre 1767): p. 93; and 'Coup d'œil général sur les peintures..., Journal de Trévoux (Octobre 1767): p. 189. 
Having thoroughly dismissed the painting's execution, Diderot then steps back and mitigates his harsh judgment by invoking the painter's gender: 'Cela n'est pourtant pas sans mérite pour une femme. Les trois quarts des artistes de l'Académie n'en feraient pas autant' (p. 370). How could Le Buveur be 'not without merit for a woman,' if three-quarters of the male academicians could not do as well? Did that estimate not place Therbusch among the top tier of French artists at the Academy? Indeed, the contradiction in Diderot's text, the condescending litote (pas sans mérite) and the patronizing concessive formula (pour une femme) are the stylistic symptoms of the critic's profound ambivalence toward the phenomenon of the woman artist - an ambivalence he shares, though he will not admit it, with the uncouth academicians who had disputed the authenticity of her painting in the first place and tried to intimidate her. Even for this indefatigable champion of Madame Terbouche, the question remains: how to reconcile the painter's artistic ambition, indeed her artistic achievement, with her female gender?

Six months after her reception at the Academy, Therbusch intended to show at the Salon a large-scale mythological painting, Jupiter, métamorphosé en Pan, surprend Antiope endormie (now lost). This was not the first mythological scene she had done, nor would it be her last. In 1764, she had executed three large works inspired by Greek mythology: Pan and Syrinx for the Pfälzischer Kurfürst Karl Theodor, and two, Venus and Dying Adonis, and Ariadne in Naxos for the Duke of Württemberg. ${ }^{26}$ These works were followed in later years by a string of other mythological paintings, such as The Toilet of Venus and Diana and her Nymphs (figs. 5 and 6), which proclaimed Therbusch's ambition in the highest genre, history painting, and demonstrated her skill in complex composition, female anatomy, and landscape. The Royal Academy's screening committee, however, rejected her Jupiter and Antiope out of hand. Implored by Therbusch to intercede with his friends at the Academy, Diderot lists the artists to whom he spoke on her behalf ('je vis Chardin, Cochin, Le Moine, Vernet, Boucher, Lagrenée'), in a word, the academic areopagus, and he claims to have written to others, but all in vain: 'tous me répondirent que le tableau était déshonnête, et j'entendis qu'ils le jugeaient mauvais.' The first question raised by this unanimous verdict is that of 'indecency.' It was quite obvious that the figure of the nude Jupiter, declaring to all spectators that Madame Terbouche had dared draw from the live model, was in itself transgressive. But apparently the nude figure 
of Antiope, 'couchée toute nue, la jambe et la cuisse gauche repliées, la jambe et la cuisse droite étendues' also raised eyebrows. Diderot slyly remarks that a few years earlier, no one had raised objections to Boucher's Odalisque, which showed a woman reclining half-naked on a daybed (the painter's wife, as he believed), 'offrant la tête la plus voluptueuse, le plus beau dos, les plus belles fesses, invitant au plaisir, et y invitant par l'attitude la plus facile, la plus commode, à ce qu'on dit même la plus naturelle, ou du moins la plus avantageuse' (p. 374) - a painting, he pungently writes, in every way suited to send his son (if he had one) straight to the whorehouse. ${ }^{27}$ Diderot's association of Therbusch's Jupiter and Antiope with Boucher's pornographic Odalisque leads one to conclude that the 'indecency' of her painting did not reside in the nudity of the figures, but in the painter's gender. Indecent was the appropriation by a female artist not only of the sexual subjects of mythology, but of the genre of mythology itself, which was the preserve of history painters, by definition all male. Boucher's name is not invoked here by coincidence. Similar in subject to many erotic metamorphoses of Jupiter painted by Boucher, Therbusch's Jupiter and Antiope could be seen as aiming to emulate the First Painter of the King (who, in 1767, was also the director of the Royal Academy) on his very territory. What gave offense, then, in Therbusch's Jupiter and Antiope, was the manifest transgression by a woman painter of the decorum, norms, and privileges that ruled history painting since the Academy's foundation. It was on similar grounds that, in 1783, the three outstanding mythological paintings presented by Vigée-Lebrun for her reception at the Royal Academy would be disregarded in favor of paintings in a genre deemed more appropriate to a woman, portraits. ${ }^{28}$

Diderot's irony about the Academy's hypocrisy regarding immoral subjects does not, however, imply an endorsement of Therbusch's Jupiter or support for the ill-used painter. In fact, he switches the focus for a moment from the artist back to the woman, to give an account of her excessive, indeed nearly demented, reaction to the committee's rejection of her mythological painting: 'Elle se trouva mal; la fureur succéda à la

27 Boucher's notorious painting, L'Odalisque brune, was executed in 1745. It was not exhibited at the Salon and the painter had not taken his wife, but Victoire O'Murphy as a model. However, copies of the painting had been made and Diderot probably saw one of those. See Diderot, Salon de 1767, p. 374 n. 646.

28 On Vigée-Lebrun's controversial reception, see Sheriff, The Exceptional Woman, chs. 3 and 4 . For a penetrating contemporary commentary on these mythological paintings, see Fort, ed., Les Salons des 'Mémoires secrets,' p. 249-53. 
défaillance; elle poussa des cris; elle s'arracha les cheveux; elle se roula par terre; elle tenait un couteau, incertaine si elle s'en frapperait ou son tableau. Elle fit grâce à tous les deux' (p. 373). Throughout his review, Diderot deftly shuttles between two poles in his representation of Therbusch's character. On the one hand, he proffers the highest admiration for a woman who was self-taught ('Elle est autodidacte'), independent (she traveled alone), professionally ambitious ('Elle a la fureur du métier'), and a philosophe in her own right, able to disregard the moral prejudices and social constraints affecting her sex when they stood in the way of her art. On the other, his review exudes contempt for her ruthless careerism, her touchy vanity, and her attacks of fury when she was crossed or frustrated in her ambitions: 'Elle est si sensible au jugement qu'on porte de ses ouvrages qu'un grand succès la rendrait folle ou la ferait mourir de plaisir. C'est un enfant' (p. 370-71). According to this Janus-like portrait, Therbusch displays, on the one hand, a manly courage (perceptible at times in her painting style, 'mâle et heurté'), on the other, an infantile behavior. This divided identity is subsumed under a third, the one which is truly only woman's, namely the hysteric - a type that Diderot is one of the very first thinkers to conceptualize in the eighteenth century. 'Therbusch' - that is, the construction of this painter that Diderot provides in his 1767 Salon - is already the split 'Woman' that the philosophe will theorize at more length in his essay 'Sur les femmes' a few years later. ${ }^{29}$

There was no reason for Diderot to review Therbusch's Jupiter and Antiope, since the painting was not exhibited at the Salon. But the critic could not resist treating his distant readers to a private visit to the artist's atelier, where he had looked at the painting as it was nearing completion, and advised the artist to retouch some details. The academicians had refused the Jupiter and Antiope on grounds of indecency, but Diderot interprets their judgment as entailing aesthetic value ('tous me répondirent que le tableau était déshonnête, et $j$ 'entendis qu'ils le jugeaient mauvais' p. 373). In his review, he faults Therbusch for her conception of history painting as naturalistic imitation: 'Cette femme pense qu'il faut imiter scrupuleusement la nature' (p. 371). But nature alone, with its beauties, but also its defects, unrelieved by the codes and conventions of painting that ennoble it, will never, in his view, produce a beautiful painting. Significantly, he prefaced his Salon of 1767 with a long philosophical

29 'La femme, hystérique dans la jeunesse, se fait dévote dans l'âge avancé; la femme à qui il reste quelque énergie dans l'âge avancé, était hystérique dans sa jeunesse.' Diderot, CEuvres, ed. André Billy (Paris: Gallimard, 1951), p. 952-53. 
disquisition on the crucial importance for the artist of keeping his mind trained on a 'modèle idéal,' a conception of painting which, opposed to the slavish imitation of nature, requires elevation, hyperbole, and 'exaggeration' if the artist is to reach his transcendent goal. In this Neoplatonic art theory, there is no place for a strict imitation of 'nature,' as nature is always thought to be flawed or corrupt. ${ }^{30}$ Diderot pithily observes that, under such circumstances, there is only one alternative for the artist, mediocrity or sublimity: 'on est pauvre, mesquin, plat ou l'on est sublime, et $\mathrm{Mad}^{\mathrm{e}}$ Therbouche n'est pas sublime' (p. 371). The sublime, needless to say, for Diderot as for other Enlightenment theorists such as Winckelmann or Burke, is closed off to woman.

Next, Diderot assumes the authority of the homme du métier to judge Therbusch's execution in the Jupiter and Antiope. He grudgingly admits that Therbusch, despite being a woman, knows how to put together a naked figure and to paint flesh: ' $C$ 'est quelque chose que $d^{\prime}$ avoir mis une grande figure de femme nue ensemble; $c$ 'est quelque chose que d'avoir fait de la chair' (p. 372). However, this faint praise, pronounced with a derisive undertone (c'est quelque chose), is a rhetorical strategy designed to throw into relief the innumerable technical shortcomings he perceives in the drawing of the two nude figures. Cochin and Grimm had condemned Therbusch's incorrect drawing - hardly surprising, since drawing was coded as the masculine element of painting, learned on models from antiquity and perfected in the study of the live (male) model. ${ }^{31}$ Diderot's review now corroborates his friends' verdicts with copious examples of Therbusch's failed anatomical drawing: 'Ce Jupiter satyre,' he writes, 'n'était qu'un vigoureux portefaix à mine plate dont elle avait allongé la barbe, fendu le pied et hérissé la cuisse.' Worse yet, the expression of the passions, the highest achievement of history painting, was, in his view, equally mangled in that figure: 'Il avait de la passion, mais c'était une vilaine, hideuse, lubrique, malhonnête et basse passion.' As for Antiope, her anatomy, he declares, is so misbegotten that Therbusch must have drawn her ' $d$ 'après sa femme de chambre ou la servante de l'auberge.' An unkind reminder of Therbusch's social milieu (her hus-

30 'Il n'y a point de milieu, quand on s'en tient à la nature telle qu'elle se présente; qu'on la prend avec ses beautés et ses défauts; et qu'on dédaigne les règles de convention pour s'assujettir à un système où, sous peine d'être ridicule et choquant, il faut que la nécessité des difformités se fasse sentir.' Salon de 1767, p. 371.

31 See Chardin's critique of this academic teaching in Diderot's Salon of 1765, édition critique et annotée présentée par Else Marie Bukdahl et Annette Lorenceau, (Paris: Hermann, 1984), p. 22-25. 
band was an innkeeper), this barb is also a reminder of her gender, since women's skills in the drawing of anatomy had to be learned on available, that is, socially inferior models. Academic theory held that noble figures could not be based on coarse models of lowly station (described as 'la nature ignoble'). Emboldened by art-theoretical self-righteousness, Diderot suddenly discharges a volley of offensive comments, pointing with a vindictive sexist animus to serious flaws in the drawing of the figure of Antiope: 'ses doigts courts, [...] ses jambes grêles, [...] ses pieds dont les orteils étaient difformes, $[\ldots]$ ' reveal 'son caractère ignoble.' Regarding 'ses chairs si molles, si flasques' (a judgment he emphasizes with a chiasmus 'si flasques, si molles'), he indulges in a little sexual joke, saying that, in Jupiter's place, he would have regretted 'les frais de la métamorphose' (p. 372). And so the review goes on, in a jocular mode laden with sexual innuendo characteristic of a contemporary male writing style (authorized by the destination of the Salon to Grimm), the effect of which is to ridicule the attempt at history painting of a woman who had no right to it, lacking proper academic training in this elevated genre. In the space of a few paragraphs, then, Therbusch's indefatigable artistic agent and promoter has turned into her fiercest detractor. Diderot's review more than vindicates the Academy's verdict: not only does it take a man to draw a sexually appealing female nude, it takes a man to conceive and execute a successful mythological painting.

The French academicians' demeanor toward Therbusch, as reported by Diderot, had been uncouth. But his own tone and address to her in her studio, to judge from his own report, are patronizing, if not downright insulting:

Seul avec elle, j'ajoutai que son Amour était monotone, faible de touche, mince au point de ressembler à une vessie soufflée, sans teintes, sans passages, sans nuances; que sa nymphe n'était qu'un tas ignoble de lis et de roses fondus ensemble, sans fermeté et sans consistance, et son satyre, un bloc de brique bien rouge, et bien cuite, sans souplesse et sans mouvement. (p. 372-73)

Lest the reader accuse him of incivility, he explains that he was whispering these comments to her in private, making sure not to be overheard by visitors in her studio. Obviously, the incivility consisted for him in the publicity, not in the substance, of his comments. But his consigning them to the pages of his Salon gives him the lie, as he insures in this way the perennity of his disparagement. In making this mordant, humiliating, critique, Diderot is doubtless playing histrionically to his audience of foreign grandees, who delighted in nothing more than witnessing their beloved philosophe and artistic oracle giving lessons to artists about the loftiness of art. But an interpretation sensitive to gender cannot 
ignore the fact that his self-elevation as an expert critic is managed here at the expense of a painter who, as a woman and as a foreigner, was doubly vulnerable. The very tone of his advice to her on the need to retouch the painting, imperious and insulting, attests to his belief in the superiority of male mind over female craft: 'Je lui disais, effacez-moi tout cela; mettez-moi cet amour en l'air ... Étendez-moi le front de ce satyre, raccourcissez ce visage niais, recourbez ce nez, étendez ces joues...' (p. 373). Whereas Diderot employs this kind of patronizing apostrophe to male painters in his Salons as an occasional art-critical strategy, in his Therbusch review, he uses it systematically to assert his aesthetic and critical authority by means of the woman artist's humiliation. ${ }^{32}$

Along with Le Buveur, Therbusch exhibited at the Salon of 1767 a number of other works, including portraits. ${ }^{33}$ Diderot dismisses them cursorily as 'faibles, froids, sans autre mérite que celui de la ressemblance', except 'une Tête de poète, où il y a de la verve et de la couleur' and his own portrait, 'nu jusqu'à la ceinture.' The original of the latter work is lost, but the image survives in a version engraved by Pierre Bertonnier in 1821 (fig. 7). ${ }^{34}$ (This engraving, which departs from Diderot's description in that it shows him with the left shoulder draped in a peplum gathered by a brooch, may have been done after a portrait of Diderot commissioned by Madame d'Épinay for Grimm, who was her lover. ${ }^{35}$ According to Diderot, a portrait had to satisfy two publics, and

32 Yet, at the very moment when the reader condemns his crass exploitation of the gender differential, Diderot backtracks and bows before Therbusch's 'character' in parrying his attack. He had hardly finished his diatribe than the painter, as he tells the story, called her visitors back and repeated to them Diderot's acerbic critiques 'avec une intrépidité,' he concedes, 'qui m'arracha en faveur de son caractère un éloge que je ne pouvais accorder à son ouvrage.'

33 Gathered under livret no. 115 (Plusieurs portraits, sous le même numéro) were also an allegorical painting, Une Femme de distinction qui secourt la peinture découragée and a genre painting, Un Grand Seigneur qui ne dédaigne pas d'entrer dans la chaumière $d u$ paysan malheureux.

34 The engraving ( $\mathrm{M}^{\mathrm{e}}$ Therbouche pin $\mathrm{x}^{\mathrm{t}}$ Bertonnier sculp.) was printed as the frontispiece of Naigeon's Mémoires historiques et philososophiques sur la vie et les ouvrages de D. Diderot in the 1821 Brière edition of Diderot's CEvres (Paris, 1821-34).

35 Diderot alludes to this portrait in a letter of October 1767 to Madame d'Épinay: 'Faites travailler Madame Terbouche; elle en a besoin. Faites achever mon portrait pour Grimm; parce qu'il sera beau et qu'il lui fera plaisir,' (Correspondance, 7: p. 172). The enamel miniature that Pierre Pasquier (1731-1806) painted after Therbusch's portrait of Diderot, exhibited in 1769, pleased the sitter: 'I'on m'a dit que je n'étais pas mal,' (Salon de 1769, p. 99). 
thus two different criteria: while contemporaries would appreciate a striking likeness, posterity would value an expert execution above anything else. ${ }^{36}$ In his review, he lets his daughter's enthusiastic reaction vouch for the first: 'elle l'aurait baisé cent fois pendant mon absence, si elle n'avait pas craint de le gâter.' But he also exalts the portrait for its peerless execution ('pour la fierté, les chairs, le faire, [il] est fort au-dessus de Roslin et d'aucun portraitiste de l'Académie'), adding that ' $\mathrm{La}$ poitrine était peinte très chaudement, avec des passages, et des méplats tout à fait vrais' (p. 375). This was quite a high rating indeed, as Alexandre Roslin, painter to the king of Sweden, was in Paris the acclaimed portraitist of the aristocracy, and as the Royal Academy, with Van Loo, Duplessis, Drouais, La Tour, and a few others, could in the 1760s boast extraordinary talent in portraiture. Diderot even goes so far as to say that Therbusch's portrait of him, placed opposite his likeness by LouisMichel Vanloo (also exhibited in 1767), which made him look like 'une vieille coquette qui fait encore l'aimable, ${ }^{37}$ played that one a bad trick ('jouait un mauvais tour'). Apparently, Therbusch's Diderot, displaying him à l'antique and looking commandingly to the right, did not give him the same concerns for his sexual identity. And yet, it is definitely sexual concerns that inform the narrative of the surprising modeling session that Diderot reports having spontaneously granted the artist:

Lorsque la tête fut faite, il était question du col, et le haut de mon vêtement le cachait, ce qui dépitait un peu l'artiste. Pour faire cesser ce dépit, je passai derrière un rideau; je me déshabillai, et je parus devant elle, en modèle d'académie. [...] J'étais nu, mais tout nu. (p. 375)

We have no way of assessing the veracity of this anecdote. Therbusch might have told a very different story. But what counts here is not so much what happened as how it was written about, for what purpose, and with what effect. In Diderot scholarship, this episode has been treated as one of the writer's idiosyncratic humorous and libertine digressions, a characteristically ribald interlude, or intermezzo, an

36 'Le mérite de ressembler est passager; c'est celui du pinceau qui émerveille dans le moment et qui éternise l'ouvrage [...] D'où je conclus [...] qu'il faut qu'un portrait soit ressemblant pour moi, et bien peint pour la postérité.' Salon de 1763, in Salons de 1759, 1761, 1763, textes établis et présentés par Jacques Chouillet, (Paris: Hermann, 1984), p. 194.

37 'Joli comme une femme, lorgnant, souriant, mignard, faisant le petit bec, la bouche en cour.' Salon de 1767, p. 81. The portrait is in the Louvre. 
'espièglerie' designed to lighten the tone of a ponderous five-hundredpage Salon. ${ }^{38}$ Any such interpretation tends to trivialize the crucial importance of this episode for Diderot's construction of the woman artist. Assuming the anecdote to be true, the text poses two discrete questions: 1. How is one to interpret Diderot's stripping naked before Madame Terbouche? 2. What function does the retelling of this anecdote play in the critical portrait that Diderot paints of her in his Salon? In answer to the first question, let us note that the decision to pose in the nude was not hers, but his, and that this decision was entirely out of proportion with the minor problem the artist was experiencing as she was painting his neck. Since the portrait was to be only bust-length, it would have sufficed for the model to remove his shirt. Diderot's complete stripping was thus excessive and seems entirely whimsical and gratuitous.

We remember, however, that the 'singularité' that Madame Therbouche was famous for in artistic circles was that she painted after the male nude. Early in his review, Diderot highlights this as a considerable and daring achievement on her part, praising the artist for rising above petty notions of decency in pursuit of her art:

Celle-ci a eu le courage d'appeler la nature et de la regarder. Elle s'est dit à elle-même, je veux peindre et elle se l'est bien dit. Elle a pris des notions justes de la pudeur. Elle s'est placée intrépidement devant le modèle nu. Elle n'a pas cru que le vice eût le privilège exclusif de déshabiller un homme. ${ }^{39}$ (p. 370)

With its succession of brief declarative statements, the syntax in this sentence underlines the artist's courageous self-affirmation and signifies the critic's approval of her artistic ambition. Yet his act of sudden and unbidden disrobing denies this, as it strives to put Therbusch to the test of her own stated principles. This act was all the more exciting for the philosophe as it opened up several avenues for empirical observation.

38 See Roth's note 15 in Correspondance, 7: p. 173: 'si vraiment il se montra "en modèle d'académie", ce fut ... par espièglerie, ou par provocation.' Roth notes the discrepancy between Bertonnier's engraving and Diderot's description: 'le portrait ne cadre pas avec ses propos.'

39 In a letter to Falconet (May 1768), Diderot opposes the right of the female painter to draw from the male nude to the lewd practice of society women to peep at naked men from the protection of their coaches: 'On permet au vice de regarder la nature, et on le défend au talent $[\ldots]$ Mille femmes lascives se feront promener en carrosse, sur le bord de la rivière, pour y voir des hommes nuds; et une femme de génie n'aura pas la liberté d'en faire déshabiller un pour son instruction?' Diderot, Correspondance, 8: p. 42 . 
Here was a way of examining first-hand a woman artist at work before the male nude model, and of seeing for himself whether she could remain impassive at the sight of the naked male body, as she claimed. Diderot's commitment to empiricist principles converged here with his vivid interest in female sexuality, as manifested in so many pages of his work, from Les Bijoux indiscrets to La Religieuse. The question whether modesty in a woman was innate or culturally ingrained was one of the most hotly debated subjects at the time. In his Lettre à d'Alembert and Émile, Rousseau had argued that female modesty was a gift of nature, but Diderot believed it was the product of convention. Another hypothesis is that Diderot seized the portrait session as a pretext for quirky exhibitionism, or to experience a virtual sex change. Fascinated by the myth of Tiresias as he was, he could now test in body and thought what it was like to sit in the nude to a painter of the opposite sex. The modeling situation afforded him the titillating opportunity to reverse the conventional gender roles and to assume the passive position of the looked-at (usually female) naked model, while Therbusch, the woman artist, dressed, and holding the brush, was in control of the gaze. ${ }^{40}$

One aspect of this startling stripping, however, has been overlooked. Diderot's act was not harmless: deliberately or not, it presented a hostile challenge to the artist, interrupting her in the very act of painting and forcing her to take account of his intrusive nakedness. Such an action was likely, if not intended, to make her lose her concentration and forget her art, however temporarily. What is more, the very nature of this prank addressed in her the conflict between modest woman and professional painter that she had sought to negate by studying the nude in defiance of social conventions. Diderot's unbidden flaunting of his nudity under her eyes when she was trying to do a bust portrait, finally, was demeaning to her by so bluntly forcing her attention back to the origin and nature of her professional difficulties, the great obstacle that stood in the way of all women painters, sexual difference.

If Diderot's outlandish behavior was a test, Therbusch passed it with flying colours, showing that she could indeed reconcile her identity as a woman with that of artist. Diderot reports that, continuing to paint unperturbed, she thanked him politely for his initiative: 'je n'aurais pas osé vous le proposer, me dit-elle; mais vous avez bien fait et je vous en remercie.' But we should be wary of concluding that Therbusch's indifference to his

40 Both Sheriff and Angela Rosenthal have written about this aspect of Diderot's text. See below and notes 43 and 44 . 
proffered maleness redounds to her credit in Diderot's eyes. What is affirmed by the absence of any sexual embarrassment on her part may be, so the text insinuates, her sexlessness, her lack of femininity, or worse. Diderot had characterized her self-taught style of painting as 'mâle et heurté.' If Therbusch paints the male nude unmoved by what she sees, one reason could be that she is, at bottom, no woman at all. Here is a very early, if not the first, instance in French art criticism of a satirical topos the woman artist as a man - that will become a pervasive strategy of denigration of women painters in the critical reviews of the 1770s and 1780s. ${ }^{41}$ Yet Diderot's text also raises questions about the sitter/critic's own sexuality. At this very moment, the narrative of the portrait session switches to the issue of male sexuality under the woman's gaze:

Comme depuis le péché d'Adam on ne commande pas à toutes les parties de son corps comme à son bras, et qu'il y en a qui veulent, quand le fils d'Adam ne veut pas, et qui ne veulent pas, quand le fils d'Adam voudrait bien; dans le cas de cet accident, je me serais rappelé le mot de Diogène au jeune lutteur, mon fils, ne crains rien, je ne suis pas si méchant que celui-là. ${ }^{42}$ (p. 375)

Ridden with teasingly enigmatic formulations and misleading negatives, Diderot's style here is deliberately opaque. Did the 'bodily part' in question have its own will, or did it not? The conditional imperfect (je me serais rappelé is an irréel du passé) makes it clear that the involuntary erection that might have happened did not, in fact, happen. ${ }^{43}$ The reader breathes more freely: decorum is safe and we are spared the unseemly mental vision of Diderot's virility displaying itself in front of Madame Terbouche as she strives to practice her métier. But what, exactly, is demonstrated by Diderot's tale of his lack of arousal?

41 See, for example, the critical pamphlet, La Bourgeoise au Sallon (à Londres et se trouve à Paris, 1787), and my forthcoming essay, 'From Galanterie to Slander: French Art Criticism of Women Painters, 1770-1787.'

42 Diderot also used this off-colour allusion to Diogenes in Bordeu's dialogue with Mlle de Lespinasse in the Rêve de d'Alembert: 'je vous dirai de ma philosophie ce que Diogène tout nu disait au jeune et pudique Athénien contre lequel il se préparait à lutter: Mon fils, ne crains rien, je ne suis pas si méchant que celui-là,' (DPV edition, 17: p. 201 n. 313).

43 One of the few critics to discuss this passage, Sheriff believes that Diderot was sexually aroused ('The woman's scientific gaze produces the same physical result as her lascivious one,' The Exceptional Woman, p. 118). But this interpretation is based on a mistranslation of the conditional past 'je me serais rappele,' 'I recalled the words of Diogenes...'). 
In her excellent book on Angelika Kauffmann and in a subsequent article, Angela Rosenthal examined this episode along with similar cases of men sitting to eighteenth-century women portraitists such as Kauffmann and Vigée-Lebrun. According to Rosenthal, the intersubjective exchange afforded by the reversal of gender identities between portraitist and sitter was exploited by female painters to control their male sitters' desires. Rosenthal cites the Diderot-Therbusch episode as one of several instances of what she shows to be a 'civilizing process' performed on men under the agency of women painters in the portrait sitting. ${ }^{44}$ According to her, Diderot, under Therbusch's controlling gaze, was able to tame his desire and rise to the stoicism expected of the moral man he hoped to be or at least to stand for. However, the text, in its very deviousness, allows for a set of less respectable interpretations. At one end of the interpretive spectrum is the image of the woman artist as castrating female, at the other is the image of the woman artist as plain Jane. Diderot, we recall, had concurred, rather ungallantly, with Cochin, Grimm, and, it seems, the entire male establishment, that Therbusch was sexually unattractive, lacking 'les tétons et les fesses,' as he gallantly wrote, to advance her career in Paris. One may assume, then, that he had little need for virtuous self-control when he posed to Therbusch in the nude. Indeed, he insists that he remained sexually unmoved during the whole session: 'Elle me peignait, et nous causions avec une simplicité et une innocence dignes des premiers siècles' (p. 375).

But this apparent sexual innocence has its own contrary signification. Given the prevalent code of galanterie and the libertine ethics of the times, ${ }^{45}$ according to which appearing in the nude before a woman meant nothing if not a sexual invitation, Diderot's lack of arousal in front of Therbusch for a long time would have struck both the artist and Diderot's contemporary readers of this episode as pointedly contemptuous of her femininity. Recall the slap (soufflet) that, in an anecdote related by Diderot in the very same Salon, the indignant comtesse de Sabran delivers to a lecherous suitor groping her in a staircase, when,

44 Angela Rosenthal, Angelika Kauffmann: Bildnismalerei im 18. Jarhundert (Berlin: Reimer, 1996), p. 154-56. Also Rosenthal, 'She's got the look! Eighteenth-century female portrait painters and the psychology of a potentially "dangerous employment,"' in Portraiture: Facing the Subject, ed. Johanna Woodall (Manchester: Manchester University Press, 1997), p. 147-66. The Diderot-Therbusch episode is discussed p. 154-55.

45 As, for example, portrayed in Claude Crébillon's La Nuit et le moment and Le Hasard $d u$ coin $d u$ feu. 
turning to him and applying her hand where she had been led to expect some 'tone,' she finds nothing $!^{46}$ It is not the sexual advance that she punishes, but its lack of motivation. Similarly, Diderot's protracted limpness after he took off his clothes, while ostensibly complimenting the painter in Therbusch, could not but be offensive both to the woman's modesty and to her sexual pride. Diderot's tale of his portrait session, then, reaffirms the insuperable contradiction at the heart of the new cultural phenomenon of the 'woman artist.'

But why tell this intimate anecdote in the Salon of 1767 ? Reflecting on the destination of the Therbusch piece, we have reason to dismiss its alleged playful poetics and regard it, on the contrary, as a deliberate attempt to undermine the artist's reputation with her foreign patrons. The very fact that Therbusch's art was discussed in the context of a sexual anecdote, even though her morals were not impugned, was enough, in combination with Diderot's unquestioned authority as an art critic and his virulent comments on her Jupiter and Antiope, Le Buveur, and most of her portraits, to impair her prestige with those of her clients who had access to his Salons. Some of Therbusch's royal patrons, Frederic II's brothers, for example, were among the subscribers to Grimm's Correspondance litterraire, and received their manuscript copies by private courier soon after Diderot handed his text to Grimm. Diderot finished the Salon of 1767 in November 1768, a week or so before Therbusch departed for Brussels and Holland on her way back to Berlin. He wrote his article on Therbusch while the painter was still in Paris, almost in daily contact with her. ${ }^{47}$ She left Paris on November 12 or $13 .{ }^{48}$ Had the issue of the Correspondance littéraire containing his Therbusch essay been

Salon de 1767, p. 128. Diderot tells this anecdote in regard to the impotent old man's lascivious expressions in Lagrenée's La Chaste Suzanne.

47 On 4 November 1768 , he wrote to Sophie Volland that he was very close to completion ('Dieu soit loué, je touche à la fin de mon Sallon,' Correspondance, 8: p. 212). Generally, Diderot gave Grimm his manuscript to copy and send out as soon as it was done. In the same letter, he reports Therbusch's financial problems, including having to settle for a cheaper lodging, and his increasing impatience with her: 'Madame Terbouche me fera devenir fou. Vous sçavez qu'elle est retombée dans l'abyme de l'hôtel garni. Un de ces matins, je ferai un signe de croix sur sa tête, et je me retirerai chez moi.' (Correspondance, 8: p. 211).

48 On 15 November 1768, Diderot wrote to Sophie Volland: 'Écoutez la bonne, la grande, l'heureuse nouvelle: Madame Terbouche est partie. Elle s'avance de dimanche au soir, entre neuf et dix, vers Bruxelles dans une chaise de poste, car elle n'a jamais voulu honorer la diligence de sa personne. Il y a cent autres traits de puérile vanité de cette force là,' (Correspondance, 8: p. 222). 
delivered on time and complete, his incriminating assessment of her, both as a woman and as an artist would have arrived at these northern courts at about the same time as she did or soon thereafter. Diderot, furthermore, had intended a full copy of his Salon of 1767 to be read publicly by Falconet to the Academy of the Fine Arts in St. Petersburg. ${ }^{49}$ Meanwhile, Diderot had helped broker the sale of Jupiter and Antiope to Catherine II. ${ }^{50}$ Why undo the patronage he had himself so generously extended to the artist early on by discrediting her person and her work in his Salon criticism?

A fragment published as Annexe IV in the DPV edition and originally intended as an accompaniment to the Therbusch piece in the Salon of 1767 sheds light on Diderot's increasing disappointment with Therbusch at the end of her Paris sojourn. ${ }^{51}$ Styling himself 'le pauvre philosophe,' and casting himself as the defendant in a mock prosecution, Diderot piles up accusations against ' 1 'indigne Prussienne.' He indicts the artist for shamelessly exploiting his friendship, pocketing advances for paintings she did not execute, and leaving behind her a huge amount of debts and howling creditors:

Le pauvre philosophe a mis à contribution les grands, les petits, les indifférents, ses amis, et a fait gagner à l'artiste dissipatrice cinq à six cents louis dont il ne restait pas une épingle au bout de six mois [...] le pauvre philosophe a calmé la furie des créanciers de la Prussienne attachés aux roues de sa chaise de poste. Le

49 In September 1768, Diderot wrote to Falconet to look for the saga of Madame Terbouche in the papers he was sending to the newly founded Academy of the Fine Arts in St. Petersburg: 'L'histoire de votre maison ne finiroit point [...] L'histoire de l'artiste qui l'occupera jusqu'à la fin de ce mois seroit encore fort longue, et vous la trouverez dans mon remercîment à l'Académie,' (Correspondance, 8: p. 128). In an earlier letter (May 1768), he had indicated that his expression of gratitude for the honourary membership the Russian Academy had lately conferred on him would be his Salon of 1767: 'Patience, ce remerciement sera un volume bien conditionné, la description complète des tableaux du Sallon: le sujet, la composition, le faire, mon jugement en un mot. Lequel jugement, rectifié, commenté par vous, fournira matière intéressante à cinquante séances au moins,' (Correspondance, 8: p. 33). However, he could not send it, as Grimm kept the original copy for two years.

50 In a letter to Falconet of May 1768, Diderot indicated that the painting was on its way to the tsarina in St. Petersburg (Correspondance, 8: p. 30). In a letter to Falconet of 14 July 1768 , the empress expressed her poor opinion of this painting: 'Il est à mon avis très mauvais; jamais on n'a fait une plus grande dépense de couleur rouge; apparemment Mme T. avait entendu parler d'imagination "couleur de rose",' (Correspondance, 8: p. 30).

51 Salon de 1767, p. 517-18. See the introduction to the Salon de 1767, p. 43. 
pauvre philosophe a garanti l'honnêteté de cette femme. Qu'est-ce que le pauvre philosophe n'a pas fait pour elle, et quelle est la récompense qu'il en a recueillie? - Mais la satisfaction d'avoir fait le bien. ${ }^{52}$

There was, as it turned out, a further object of concern on Diderot's part, namely the rumor that he had helped the artist along in Paris in return for sexual favors (ironically, the very offense he had denounced as rampant among academicians): 'le pauvre philosophe, dont on a mésinterprété l'intérêt, a été calomnié et a passé pour avoir couché avec une femme qui n'est pas jolie. ${ }^{53}$ The anecdote of his sexual 'innocence' while sitting in the nude to Madame Therbusch in her studio was designed, if nothing else, to convince his readers not only that he had not had a liaison with his protégée, but, and this is not negligible, that he was not a man to sleep with plain Janes. The whole piece can be regarded as a pro domo defense written by the critic to restore his good name for posterity, at the expense of the woman painter's.

The image of Therbusch that emerges from Diderot's review in the Salon of 1767 is devastating: a mediocre draftswoman, a poor colourist given to an excess of red, a would-be painter of mythological scenes who took slatterns as models and miserably failed to ennoble the expressions of her figures, an artist incapable of rising to the sublime, a Teutonic painter who stubbornly adhered to her stodgy German style and was incapable of taking the friendly advice of a polished French connoisseur such as Diderot, a woman of unstable, indeed hysterical, temperament, ungrateful, disloyal, and dishonest. In this harsh verbal portrait of the woman artist, which unkindly repaid the warm and beautiful visual likeness she had done of him, Diderot did not just depict 'Madame Terbouche.' Using his Salons as a means of personal vindication, he transformed art criticism into a gendered weapon that could be used against the encroachments of 'women artists' and provided a blueprint for later attacks on female painters. If Diderot had been temporarily castrated by Therbusch's cool professional gaze during the portrait session, he now got revenge thanks to his mighty pen. Writing for

52 Salon de 1767, p. 517. A letter to Sophie Volland of 22 November 1768 corroborates briefly the detailed accusations of the 'Annexe IV' against Therbusch: 'J'ai démontré à notre artiste, deux heures avant son départ, qu'en moins de quinze mois, elle avait dépensé à peu près huit cent louis. Elle est partie. Elle est à Bruxelles. Le prince [Golitsyn] la remettra dans sa patrie, dans sa famille, avec dignité, et ce ne sera pas de ma faute si son fils n'est pas secrétaire d'ambassadeur,' (Correspondance, 8: p. 230). 
posterity, as he claims he always did, he certainly knew the lasting damage that a review of this order could do to her reputation.

By a quirk of fate, however, the subscribers of the Correspondance littéraire received only the first two issues of the Salon of 1767 and thus not the Therbusch article. ${ }^{54}$ The text of this Salon had grown to such extravagant proportions that Grimm decided to distribute it separately, but procrastinated.$^{55}$ Therbusch was thus spared from its possible adverse effects. She had hardly left Paris when she was received as an honourary member of the Academy in Vienna. ${ }^{56}$ After her return to Berlin, Frederic II commissioned from her not only portraits of the royal family, but also decorative paintings for his châteaux in Potsdam and Sanssouci. ${ }^{57}$ Therbusch went on to pursue a lucrative and honourific career, prompting her first biographer to write that she was in all respects a rare and deserving woman. ${ }^{, 58}$

Nevertheless, Diderot's damaging piece on Therbusch had an afterlife. It was copied, first in the Leningrad and Vandeul copies of Diderot's Salons in the Correspondance littéraire, then in the first edition of Diderot's works by Naigeon (vol. 14, 1798) and in subsequent editions, without the information that might deepen a reader's understanding of its gendered animosity. Since Cochin managed to silence all anonymous art reviews in 1767, there is, beyond the brief comments in the subsidized or tolerated journals such as Le Mercure de France and L'Année littéraire, no independent voice to counter Diderot's hostile piece on Therbusch's art in the contemporary critical literature. Diderot's review is his only

54 The first two livraisons correspond to p. 55-117 of the modern DPV edition (which counts 508 pages). The Therbusch essay takes up p. 369-77.

55 In late 1769 Diderot was still asking Grimm to return his manuscript, so he could correct some errors (Correspondance, 9: p. 190). On the history of the ms copies of the Salon of 1767, see the introduction, p. 34-43.

56 She was received on 6 December 1768 with a mythological painting, Artemisia Weeping over her Husbamd Mausolos (WV no. 188 in Berckenhagen, p. 157). She later gave the Academy the portrait of her compatriot, the landscape painter Johann Georg Hackert, painted while she was in Paris.

57 See Berckenhagen, p. 125-27.

58 Katharina Küster took this quotation: 'Sie war in allem Betracht eine seltne und verdienstvolle Frau' from Meusel (p. 274) as the title of her essay on Therbusch in Lebenslust und Frömmigkeit: Kurfürst Karl Theodor (1724-1799) zwischen Barock und Aufklärung, ed. Alfred Wiczorek et al., 2 vols. (Regensburg: Pustet, 1999), 1: p. 255-60. 
extended statement on art by a woman. ${ }^{59}$ As the first textual construction of the 'woman artist' in French art criticism, it points the way to the disparagement of female art that would become standard in decades and centuries to come.

A recent reincarnation of the Diderot-Therbusch episode in a play by Eric-Emmanuel Schmitt and a film by Gabriel Aghion entitled Le Libertin testifies to the enduring power of Diderot's sexual (de)construction of the woman artist in French culture today. Le Libertin, published in 1997 by Eric-Emmanuel Schmitt along with a doctoral thesis on Diderot ou la philosophie de la séduction, ${ }^{60}$ is a rambling farcical comedy about the philosophe's vain attempts to write the article 'Morale' for the Encyclopédie in the midst of his philandering with various women gathered in Baron d'Holbach's country château at Grandval, including 'Madame Therbouche.' The play is directly based on Diderot's portrait sitting in the Salon of 1767. But, subscribing to a poetics that is as libertine as its title character, it also takes several liberties with Diderot's original text, injecting into the dialogues numerous reminiscences from a vast range of Diderot's writings. For example, the play begins with 'Therbouche' at her easel reprimanding 'Diderot' for his incapacity to hold an expression - a witty reference to the writer's own critique of his 1767 portrait by Van Loo, where he expatiated on the difficulty for the portraitist of catching transitory expressions on canvas. ${ }^{61}$ In the film, 'Diderot' is played by Vincent Perez with a winning combination of bashfulness and sexual promiscuity, and 'Therbouche' by Fanny Ardant, whose loose brown hair and consummate seductiveness seem modeled on the painter's 1761 Self-portrait (fig. 3). From the start, 'Therbouche' and 'Diderot' are involved in flirtatious banter, maintained over a series of constantly interrupted and thus constantly deferred portrait sittings,

59 Diderot stopped reviewing the Salon in 1781 (and died in 1784), thus had nothing to say about Vigée-Le Brun and Labille-Guiard, who came to the fore in 1783.

60 Both were published in Paris with Albin Michel.

61 Compare Schmitt, Le Libertin, p. 12, 'Mme Therbouche: Arrêtez de changer d'expression, je n'arrive pas à vous saisir. Allons! Il y a une seconde vous étiez pensif, la seconde suivante vous aviez l'air rêveur et voilà maintenant que vous affichez une mine désolée. En dix minutes, vous avez cent physionomies diverses,' with Diderot's famous critique of his portrait by Louis-Michel Van Loo: '...Mes enfants, je vous préviens que ce n'est pas moi. J'avais en une journée cent physionomies diverses, selon la chose dont j'étais affecté. J'étais serein, triste, rêveur, tendre, violent, passionné, enthousiaste. Mais je ne fus jamais tel que vous me voyez là,' (Salon de 1767, p. 82). 
whose eventual end is sexual consummation. Meanwhile they discuss in proto-eighteenth-century language such 'libertine' subjects as the influence of free will on sexuality or the difference between male and female pleasure. Profound modifications occur, however, in regard to plot, characters, and gender ideology. The most radical change consists in endowing 'Therbouche' with powerful sexual drives and turning her into a highly seductive, but also predatory femme fatale. Schmitt and Aghion accordingly transform Diderot's representation of the serene portrait sitting into a helter-skelter hot pursuit of steamy sex, at the height of which 'Therbouche,' a Merteuil du ruisseau, proclaims a vibrant sexual manifesto. ${ }^{62}$ The sexual positioning of the participants in the portrait session is thus reversed, and so is the balance of power. It is now 'Therbouche' who suggests that 'Diderot' take off his clothes and she who forces the coy philosophe, who has been sitting naked and embarrassed, with crossed legs, to strike a pose with legs open - a sequence which the film exploits with great relish from different angles.

In accordance with the Merteuil-like makeover of the female character, the play deepens Diderot's misogynistic representation of 'Therbouche' as a scheming adventuress. The spectator learns that she sets up her atelier in a remote pavillion of the château to get access to a large collection of valuable French and foreign paintings waiting to be shipped to the empress of Russia. The careless squandering of money of which Diderot accused the artist in his fragment of 1768 is aggravated here into premeditated grand larceny. While 'Therbouche's' acquisitive rapaciousness focuses in the play on works by French painters she cannot hope to emulate (she steals a Chardin) ${ }_{1}^{63}$ in the film, she stoops to vulgar theft, going on a looting rampage and stealing her hosts' silver and jewelry. Schmitt and Aghion add to her many vices those of spy and

62 'Le sexe, c'est la guerre. Au matin, devant ma coiffeuse, je me crêpe, je me maquille, je fais la coquette: je me prépare à mener l'assaut. [...] Je dois plaire. Ah ça, vous les hommes, vous ne comprenez pas... Plaire, pour vous, ce n'est qu'un marchepied pour arriver au lit, un moyen pour parvenir à vos fins. Tandis que plaire, pour nous, les femmes, c'est une fin en soi, c'est la victoire elle même. Séduire... je veux que rien ne soit soustrait à mon empire [...] Ah oui, vous avez la force, le pouvoir? Moi, je réduis cela à rien, je vous fais revenir au point de départ, je vous renvoie en arrière, je vous rends nus, déculottés, infirmes, sans défense, à quelques jours de vie, un gros bébé fessu entre les cuisses d'une femme,' (Le Libertin, p. 142-44).

63 This is freely based on Diderot's indication in his fragment (Annexe IV) that Therbusch's jealousy and hatred of the academic establishment turned to specific invective: 'L'indigne Prussienne traite nos La Grenée, nos Vien, nos Vernet d'infâmes barbouilleurs,' (Salon de 1767, p. 518). 
informer, as she agrees to pass on the secrets of Diderot's clandestine printing of the Encyclopédie in the château's cellar to an emissary of the Catholic Church. At the last minute, however, as she departs for Holland, 'Diderot' persuades her to switch camps and become his own clandestine agent with the Amsterdam printers for the publication of the Encyclopédie. Although 'Therbouche' is thus recuperated in extremis for the cause of Enlightenment, she is nevertheless portrayed throughout the film as opportunistic and immoral, driven by greed and sexual instincts, and available to the highest bidder - an image which, surprisingly, resurrects some of the slanderous criticism written about Elisabeth Vigée-Lebrun in the 1780s.

Most significantly, Schmitt and Aghion up the ante on Diderot's portrait of Therbusch as an inferior artist. In the play and the film, she is a sham painter, pretending to paint as an alibi for defrauding people of their possessions. ${ }^{64}$ After she leaves, her portrait of 'Diderot' is discovered in the château: but it is only a rough sketch drawn on paper. The play and the film thus deny the woman artist the power to paint and debase her skills to mere sketching - a crude reinterpretation of Cochin's, Grimm's, and Diderot's own negative evaluations of her artistic performance. Worse yet, the rough sketch expected to show Diderot's portrait is discovered to be a headless 'académie' reduced to a grotesque male member. This priapic drawing, which proclaims Diderot's flashy virility against his own testimony, turns 'Madame Therbouche' into a pornographic artist of the lowest caliber. While grossly unfaithful to Diderot's text and even more unjust to Therbusch's art, this final sexualized construction of the painter drives home the misogynous subtext of Diderot's review: the reduction of the woman artist to one basic denominator, her gender, here equated with her sexual drives.

One might object that taking this critical perspective on Le Libertin leaves no room for appreciation of the delightful comedy penned by

$64-$ Mme Therbouche [...] Je n'entre chez les gens que pour en sortir avec leurs biens, la peinture me sert de prétexte pour arriver aux bijoux, à l'argent, aux coffrets, à tout ce qui se trouve à prendre.

-Diderot (mauvais). Savez-vous peindre seulement?

-Mme Therbouche. J'esquisse. Il est rare que je doive finir un tableau. La tête, surtout... Les gens sont tellement infatués d'eux-mêmes que la perspective de poser pour la postérité leur fait quitter toute méfiance; je les détrousse dès leurs premières séances; je laisse le tableau en chantier.

-Diderot. Comment se fait-il qu'on ne le sache pas?

-Mme Therbouche. Personne ne se vante d'être aussi stupide. Et puis, je change souvent de pays. (p. 136-37). 
Schmitt and translated into raucous scenes by Aghion's cinematic genius. It is true that one shouldn't look for philosophical seriousness, and even less for historical or intertextual integrity, in a play and a film whose authors aim to recapture the 'esprit libertin' for which the French nation was famous in the eighteenth century. Theirs is a glorified but by now utterly stereotypical conception of libertinism which, via the many books of Philippe Sollers and others, has entered French popular culture and feeds a prosperous film industry. ${ }^{65}$ But it may be useful to recall that such works, then and now, thrive on views of gender that reinforce traditional hierarchies and prejudices rather than questioning them. Which is why it is high time to liberate Anna Dorothea Therbusch from the damaging image of her cast by her French detractors.

BERNADETTE FORT

Northwestern University

65 In his review of a theatrical performance of Le Libertin in Montréal, Benoit Mélançon also mentioned 'l'imagerie culturelle qui sous-tend nombre de représentations actuelles du XVIIIle siècle,' among which he cites Molinaro's Beaumarchais and Philippe Sollers's Casanova, 'Séduire et plaire,' Jeu 89 (December 1998): p. 21. 


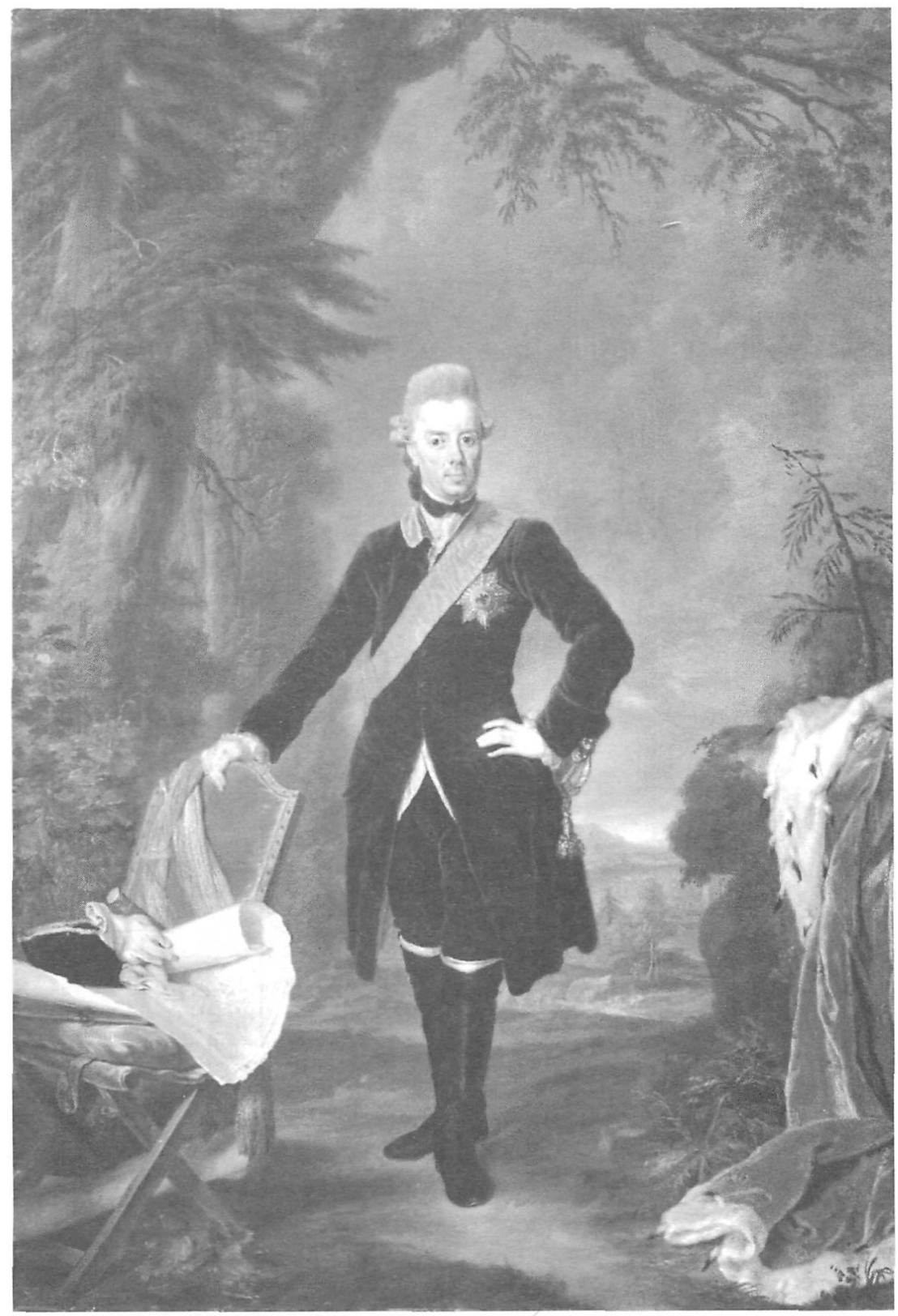

Figure 1. Anna Dorothea Therbusch, Prinz Henrich von Preußen. Potsdam, Neues Palais. Stiftung Preußiche Schlösser und Gärten, Berlin-Brandenburg. 


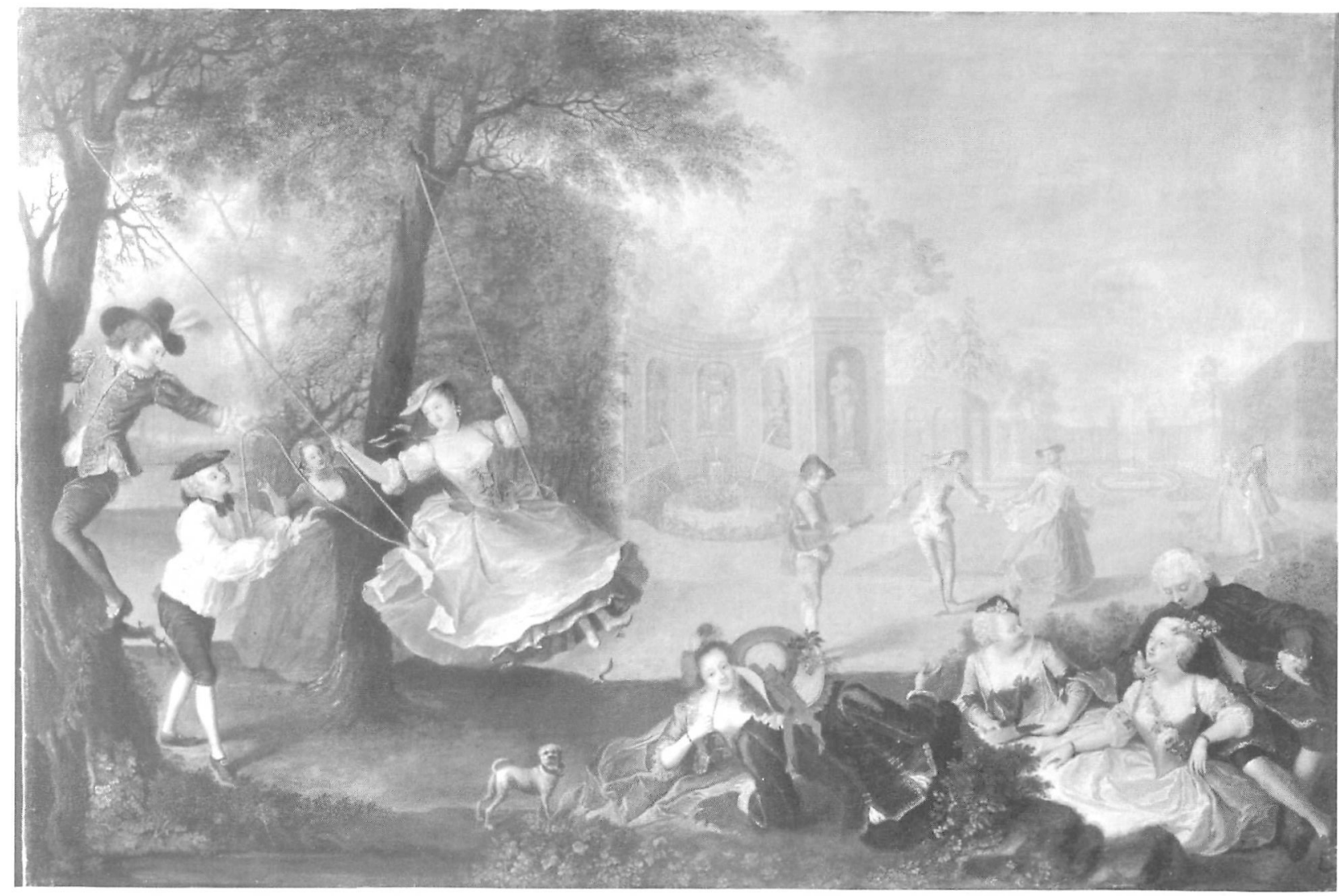

Figure 2. Anna Dorothea Therbusch, The Swing. Potsdam, Neues Palais. Stiftung Preußiche Schlösser und Gärten, Berlin-Brandenburg. 


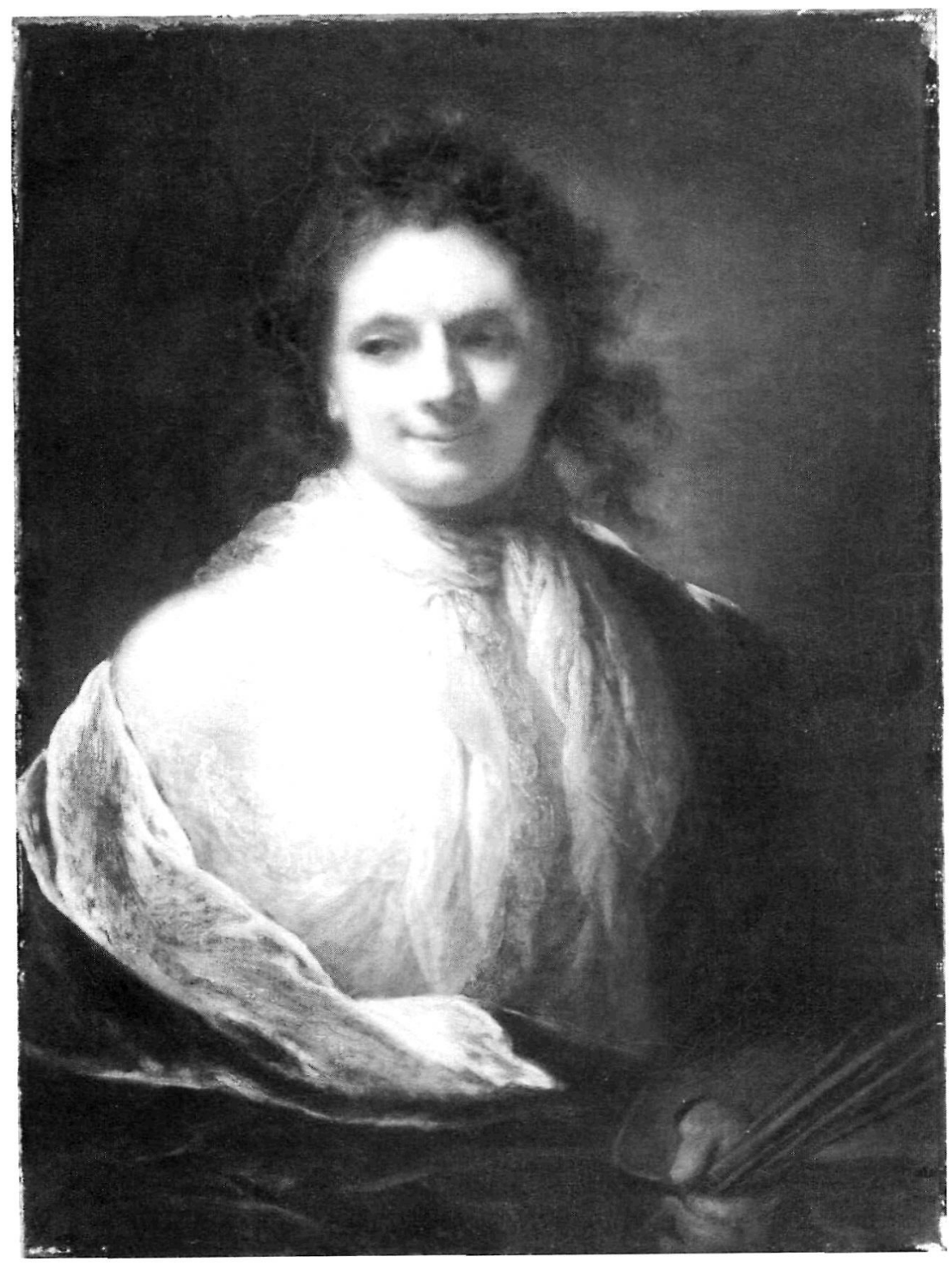

Figure 3. Anna Dorothea Therbusch, Self-Portrait. Stuttgart, Staatsgulerie 


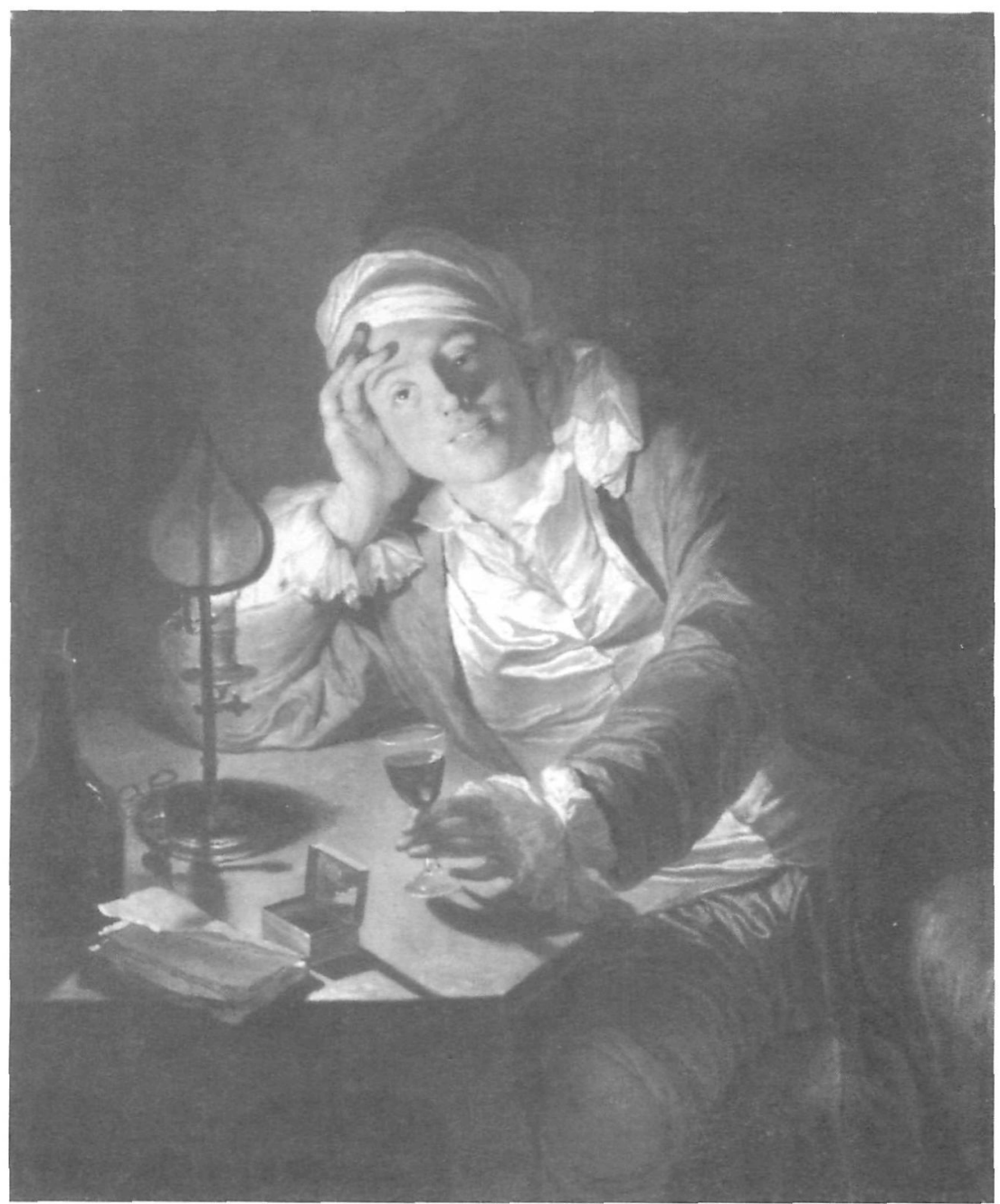

Figure 4. Anna Dorothea Therbusch, Un homme, le verre à la main, éclairé d'une bougie (Le Buveur). Paris, École nationale supérieure des beaux-arts. 


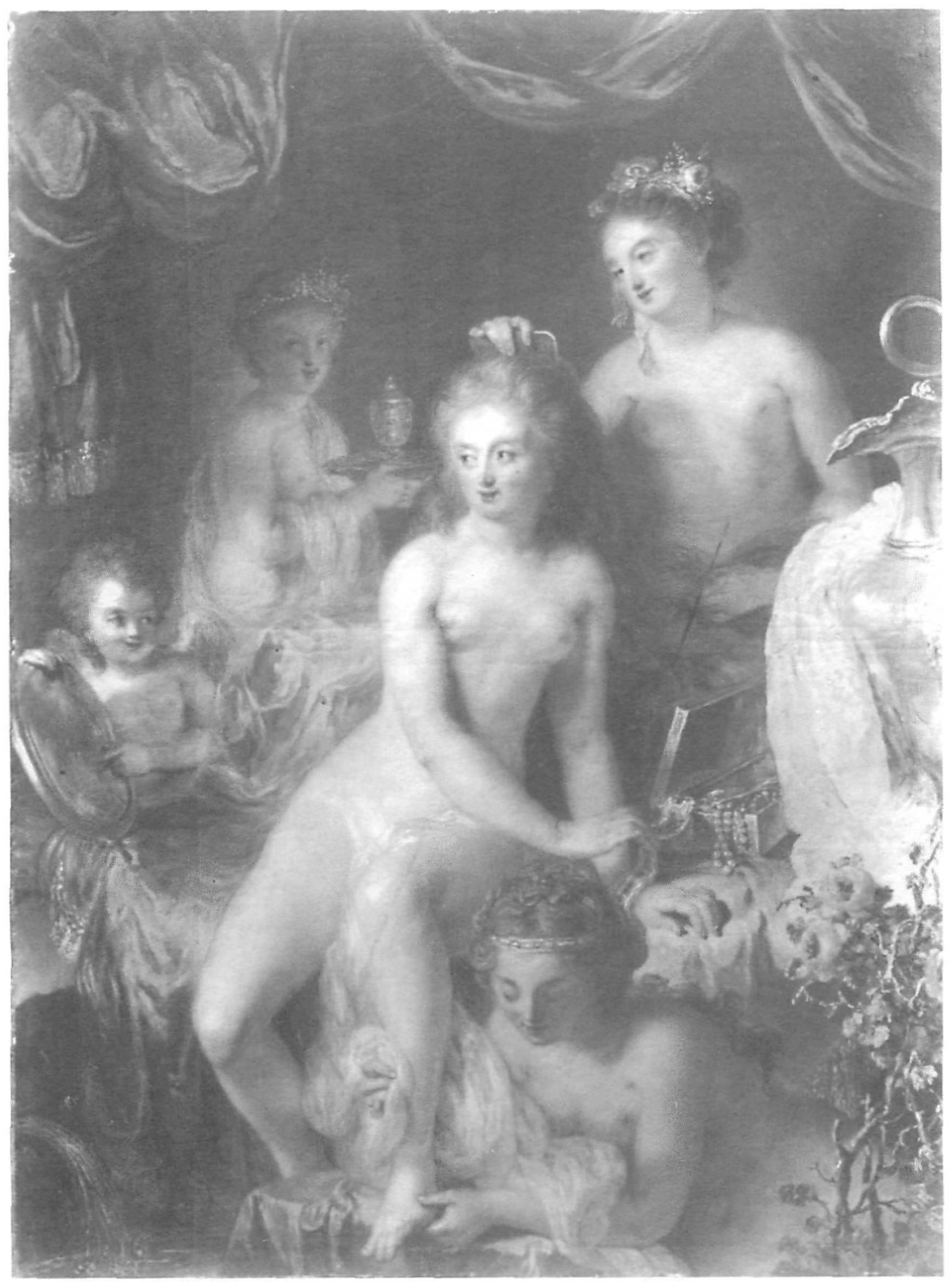

Figure 5. Anna Dorothea Therbusch, The Toilet of Venus. Potsdam, Neues Palais. Stiftung Preußiche Schlösser und Gärten, Berlin-Brandenburg. 


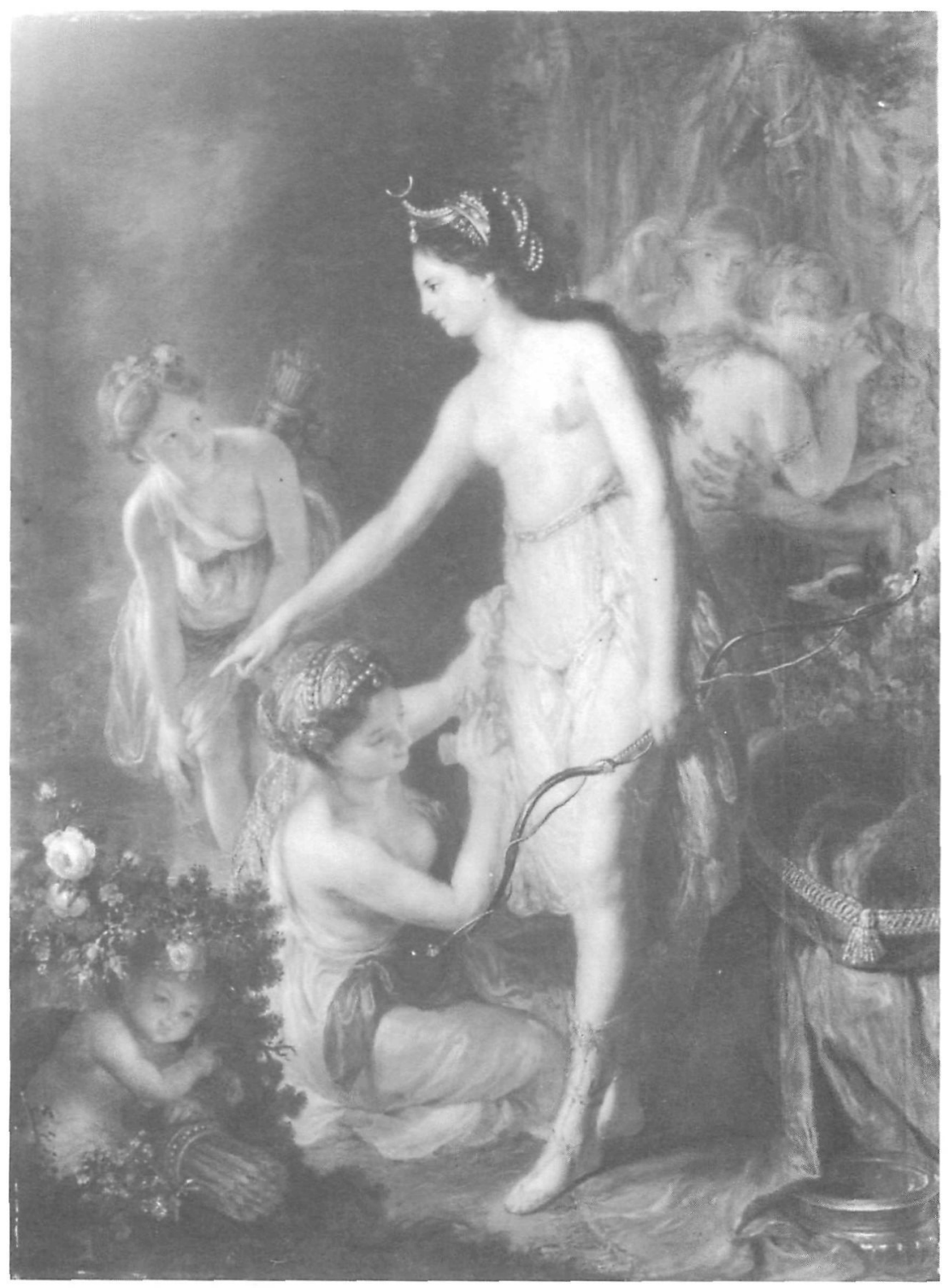

Figure 6. Anna Dorothea Therbusch, Diana and her Nymphs. Potsdam, Neues Palais. Stiftung Preußiche Schlösser und Gärten, Berlin-Brandenburg. 


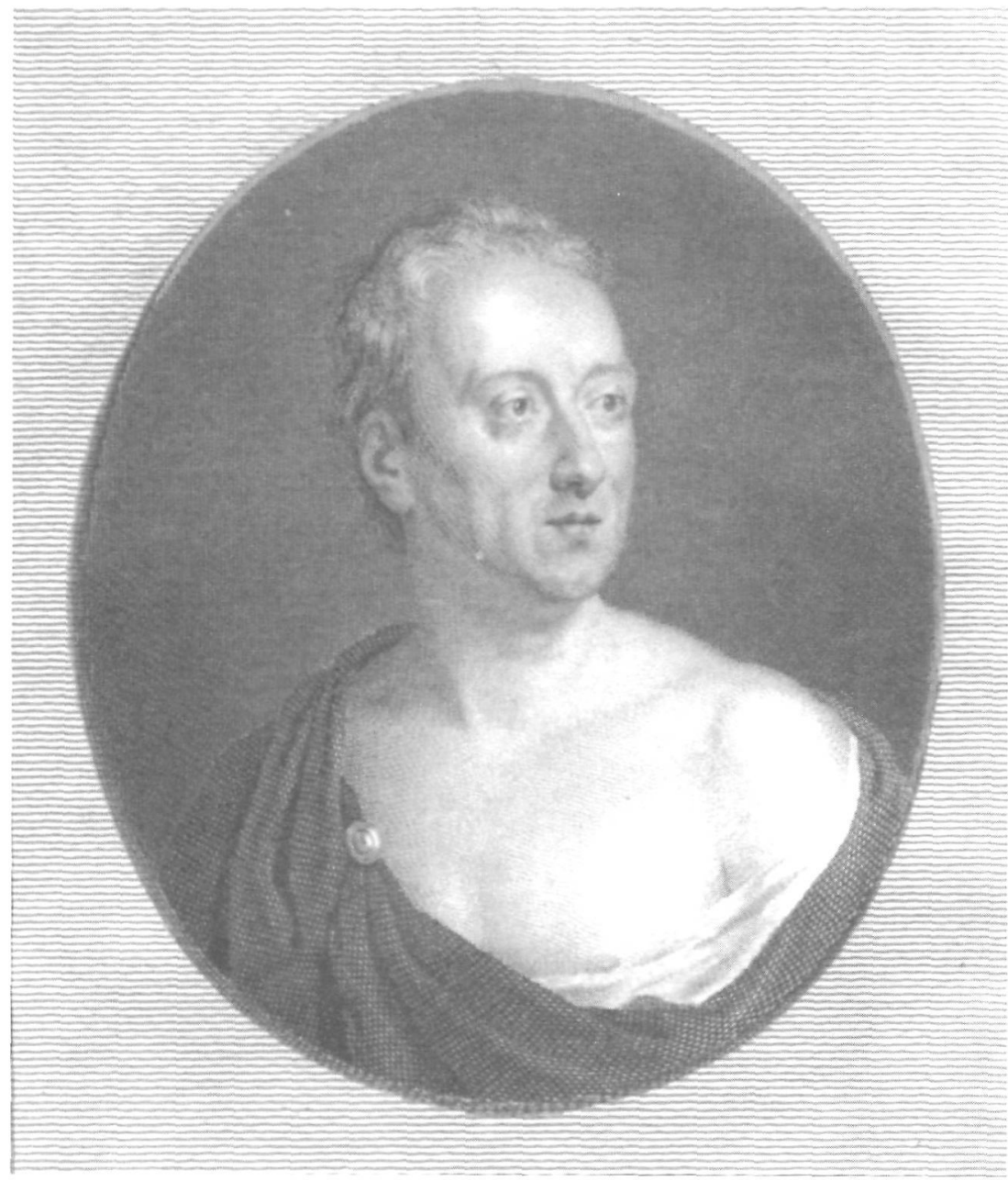

Figure 7. Denis Diderot. Engraving by Pierre Bertonnier after Anna Dorothea Therbusch. 